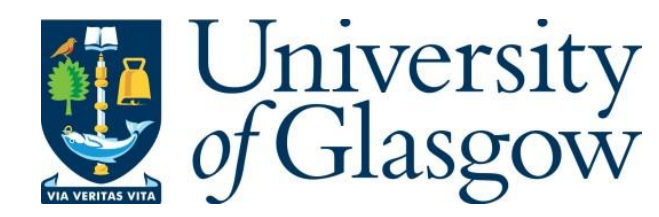

Jaud, M., Kukenova, M. and Strieborny, M. (2018) Finance, comparative advantage, and resource allocation. Review of Finance, 22(3), pp. 1011-1061.

There may be differences between this version and the published version. You are advised to consult the publisher's version if you wish to cite from it.

http://eprints.gla.ac.uk/196300/

Deposited on: 4 November 2019

Enlighten - Research publications by members of the University of Glasgow http://eprints.gla.ac.uk 


\title{
Finance, Comparative Advantage, and Resource Allocation*
}

\author{
Melise JAUD ${ }^{\dagger} \quad$ Madina KUKEnOvA ${ }^{\ddagger} \quad$ Martin StRIEBornY ${ }^{\S}$
}

Final WP version: 28th July 2017

\begin{abstract}
Can financial institutions and markets enhance the discipline imposed by competitive product markets and thus improve resource allocation in the real economy? We address this question in the context of international trade, using disaggregated product-level data from 71 countries exporting to the USA. We show that exported products exit the US market sooner if they stand far away from the exporting country's comparative advantage. This pattern is stronger when the exporting country has a well-developed banking system, but it is unaffected by the depth of stock markets. These results are in accordance with theories stressing the disciplining role of debt and monitoring abilities of banks.
\end{abstract}

JEL classification: G21, G30, F11, O16.

Keywords: disciplining role of finance, product and financial markets, export survival

${ }^{*}$ This paper has been now published in Review of Finance. Please refer to the journal's website for the final version of the paper and online appendix. We would like to thank Jean Imbs, Thorsten Beck (Review of Finance editor), Tibor Besedes (discussant), Chad Bown, Marius Brülhart, Olivier Cadot, Alan Deardorff, Shantayanan Devarajan, Jens Forssbaeck, Reto Föllmi, Caroline Freund, Amit Goyal, Andrei Levchenko, Frederik Lundtofte, Alberto Paloni, Ryan Peters (discussant), Jun Qian (session chair), Akiko Suwa-Eisenmann, Mathias Thoenig, Anders Vilhelmsson, Tianxiao Zheng (discussant), a Review of Finance referee, a World Bank referee, as well as conference and seminar participants at the China International Conference in Finance 2016, University of Michigan - Ann Arbor, GothenburgLund Workshop in Finance, Lund University, IFN Stockholm, EIIT Conference, Midwest Meeting in International Trade, 6th FIW Research Conference "International Economics", and 8th Australasian Trade Workshop for very helpful comments and suggestions. All remaining errors are ours. Melise Jaud and Martin Strieborny appreciate the financial support from the Swiss National Science Foundation. Martin Strieborny further appreciates financial support from the Handelsbanken Research Foundation.

${ }^{\dagger}$ University of Lausanne and World Bank; E-Mail: melise.jaud@unil.ch

${ }^{\ddagger}$ Business School of Lausanne; E-Mail: madina.kukenova@bsl-lausanne.ch

${ }^{\S}$ Knut Wicksell Centre for Financial Studies, Lund University, P.O. Box 7082, S-220 07 Lund, Sweden. E-Mail: Martin.Strieborny@nek.lu.se 


\section{Introduction}

Can well-functioning financial institutions and markets enhance the discipline provided by product markets and help avoid waste of scarce resources? The question is important because product markets often represent a rather slow-acting disciplining force (Jensen, 1993). And on the conceptual grounds, the answer seems to be affirmative. According to Levine (2005), creditors and shareholders can often improve the resource allocation by inducing managers to maximize firm value. The immediate threats of bankruptcy by creditors (Grossman and Hart, 1982) or takeover through the stock markets (Scharfstein, 1988; Stein, 1988) seem to be particularly strong devices enabling financial agents to enhance the ultimate but slow-acting disciplining impact of product markets on firms' behavior. ${ }^{1}$ However, it can be at times challenging to distinguish empirically between the disciplining effects of financial and product markets. The quality of financial markets and institutions and the quality of product markets are namely often correlated both across countries and across geographic and administrative units within countries. For example, the overall legal framework and government regulations affect the potential efficiency of the disciplining pressures imposed by both financial agents and product markets.

Our paper attempts to disentangle the disciplining effects imposed by well-developed financial institutions and markets from that of the product markets in the context of international trade. Our identification strategy consists of a difference-in-difference approach using data on more than 4,500 different products exported to the United States (USA) by 71 countries at different stages of financial development. The impact of financial markets and institutions is captured by the varying strengths of banks, stock and bond markets across countries exporting to the USA. The disciplining effect of product markets is captured by the varying level of expected competitive pressures faced by a given product in the US destination market. Our measure of these product market pressures is motivated by the Heckscher-Ohlin theory of comparative advantage in international trade and captures the extent of discrepancy between each product's revealed factor intensity and each country's factor endowment. Intuitively, exported products that extensively use factors of production (e.g., physical or human capital) that are scarce and therefore expensive in the exporting country will face much stronger headwinds in the highly competitive US destination market.

There are several advantages in using the international trade framework for examining the

\footnotetext{
${ }^{1}$ Besides complementing the discipline imposed by the product markets, financial markets and institutions can improve resource allocation also by monitoring the firms and providing valuable information about them to other agents, thereby decreasing information asymmetries in the economy. This task can be executed both by banks (Allen, 1990; Bhattacharya and Pfleiderer,1985; Boyd and Prescott, 1986; Diamond, 1984; Ramakrishnan and Thakor, 1984) and by stock markets (Grossman and Stiglitz, 1980; Holmstrom and Tirole, 1993; Merton, 1987).
} 
disciplining role of finance and product markets. First, we can reasonably assume orthogonality between the competitive pressures in the US product markets and the varying levels of strength of financial markets and institutions across countries exporting their products to the United States. The bilateral character of the international trade data thus allows us to better distinguish the impact of financial markets and institutions that are measured at the exporting country level from the impact of product markets in the US destination market. Second, the international trade data are highly disaggregated, internationally comparable, and available for a large set of different countries and products. Table XII in the Appendix A provides some examples of different product categories to convey a better idea about the level of disaggregation in our data. This allow us to control for product heterogeneity at a sufficient level of disaggregation while at the same time minimizing the problems of comparability and external validity that arise in the context of existing national data classification on domestic production. In particular, there are no readily available firm level data on domestic production that would be both internationally comparable and available for a large number of countries. Third, there is the issue of reverse causality between financial factors and outcomes in the real economy. For example, Greenaway, Guariglia, and Kneller (2007) find no evidence that firms with a better ex-ante financial health are more likely to enter foreign markets. They do, however, find strong evidence that firms' financial health improves once they start exporting. This result poses serious challenge for studies examining whether better developed financial institutions and markets promote exports of financially vulnerable firms. ${ }^{2}$ The utilization of product data can help to address this issue. In particular, the lack of product's congruence with the comparative advantage of the exporting country (distance to comparative advantage - $\left.D C A_{c k, t_{z}}\right)$ is a technological characteristic capturing the extent to which the product's manufacturing process uses up production factors that do not correspond to the factor endowment of a given economy. Presumably, neither the various political factors affecting export performance nor the export performance itself will alter the capital or labor intensity of individual products.

Our empirical results confirm that the larger the distance between the exported product's revealed factor intensity and the exporting country's factor endowment, the sooner the product exits the US destination market. Our measure of distance to comparative advantage thus seems to be a good proxy for competitive pressures facing a given product. Highly competitive product markets in the USA indeed force out exporters who rely mostly on scarce and expensive production

\footnotetext{
${ }^{2}$ Berman and Héricourt (2010) address this issue when examining the selection role of finance with respect to exporting. They look at firm's productivity rather than just its financial health and show that productivity is an important determinant of export decision only after some threshold of financial development is reached. However, subsidies or political connections could still affect both productivity and export performance at the firm level.
} 
factors from the exporting country. Although not the main point of our paper, this result is certainly interesting on its own and warrants further research.

Crucially, the products whose factor intensity puts them at a comparative disadvantage exit the US market even faster if the exporting country has a well-developed banking system. Strong banks in the country of origin thus seem to reinforce the disciplining impact of a competitive destination market on the international trade flows. Interestingly, we do not find the same reinforcing effect in the case of deep and liquid stock markets in the exporting countries. These findings are robust to a battery of sensitivity checks, including the use of various proxies for the strength of banks, stock and bond markets and alternative ways of measuring distance to comparative advantage. We thus see the main contribution of our paper in providing new evidence about the unique importance of banks in enhancing the disciplining impact of product markets and improving resource allocation in the real economy. In that sense, the paper contributes to three strands of literature examining the impact of finance on real economy.

First, our finding that well-developed banks but not deep stock markets can push country's exports towards products congruent with its comparative advantage provides empirical support for theories stressing the disciplining role of debt (e.g., Stiglitz, 1974; Grossman and Hart, 1982; Jensen, 1986; Harris and Raviv, 1990; Stulz, 1990; Hart and Moore, 1995; Aghion, Dewatripont, and Rey, 1999) and the superior monitoring abilities of banks (e.g., Stiglitz and Weiss, 1983; Diamond, 1984; Fama, 1985). In Section 2, we present a simple model of our own that illustrates how a welldeveloped banking sector can enhance the incentive impact of product market competition in the context of international trade. One could also see our results in the light of an idea introduced by Allen (1993), building upon the conceptual framework of Diamond (1984). Allen (1993) argues that banks will have advantage over stock markets in monitoring firms when there is a broad consensus on what the firms should do and the main issue is to ensure that these actions are indeed taken by the firms' management. Arguably, this is exactly the situation when it comes to the question whether firms should focus on exporting products that correspond to the comparative advantage of the country of origin, in particular if their destination market is the highly competitive US market.

Second, an influential strand of finance literature has examined the role of financial development in improving the allocation of physical capital (e.g., Wurgler, 2000; Beck and Levine, 2002; Love, 2003). In our paper, we utilize the framework of international trade to complement this scholarly work in two dimensions. For one thing, we are able to examine the impact of finance on resource allocation in a much more disaggregated setting at the level of individual products rather than 
industries while still having the benefit of using data comparable across a wide range of countries. Moreover, using trade data and the concept of revealed factor intensity allows us to compare products' factor intensities with countries' factor endowments and thus examine the disciplining role of finance in a somewhat broader context of the allocation of production factors that include physical capital, human capital, and natural resources. ${ }^{3}$ The focus on the overall resource allocation relates our paper to Fisman and Love (2004) who develop two indirect tests for examining the role of finance in resource allocation based on the idea that industry global shocks are correlated across countries and that countries at similar levels of per-capita income should experience demand-driven similarities in their industrial growth rates. Another important paper in this area is Bekaert et al. (2007) which stresses the importance of financial openness rather than domestic financial development for the capital allocation. We do not examine the issue of financial openness in our framework as it is covered elsewhere (Jaud, Kukenova, and Strieborny 2016).

Third, the paper contributes to the growing body of scholarly work on the effects of finance on international trade. This literature has provided empirical support for the importance of wellfunctioning financial environment for countries' and firms' successful export performance in two ways. It has showed that domestic financial development improves export performance, particularly for industries dependent on external finance and firms facing credit constraints (e.g., Beck, 2002, 2003; Ju and Wei, 2005; Greenaway, Guariglia, and Kneller, 2007; Manova, 2008; Jaud, Kukenova, and Strieborny, 2009; Berman and Héricourt, 2010; Becker, Chen, and Greenberg, 2013; Manova, 2013; Besedes, Kim, and Lugovskyy, 2014; Jaud, Kukenova, and Strieborny, 2015). A related strand of papers has explored the negative impact of disturbances in the financial system on trade performance, especially during the recent global financial crisis (e.g., Bricongne et al., 2010; Amiti and Weinstein, 2011; Levchenko, Lewis, and Tesar, 2011; Chor and Manova, 2012; Paravisini et al., 2015). Our paper complements these findings by showing that a well-developed banking system does not provide non-discriminate support for all kinds of exports. Instead, we provide evidence suggesting that banks do specifically promote exports on the "right side" of the comparative advantage. While providing the necessary funds for the often expensive exporting activities, banks in the countries of origin seem also to reinforce the discipline imposed by the product markets in the destination country.

The rest of this paper is structured as follows. Section 2 outlines a simple theoretical framework while the remaining sections comprise the empirical analysis that constitutes the main focus of the

\footnotetext{
${ }^{3}$ Most of our estimations focus on the physical and human capital. Table X confirms that our results extend to natural resources as well.
} 
paper. Section 3 and 4 discuss the data and our empirical strategy, respectively. Section 5 reports our main results and Section 6 offers a series of robustness checks. Section 7 concludes.

\section{An Illustrative Model}

To provide additional motivation for our empirical approach, this section presents a simple model centering around an agent who maximizes perks associated with her position as export manager while taking into account the competitive pressures in the destination market and the probability of obtaining export financing in her country. ${ }^{4}$ Like the rest of our paper, the model deliberately focuses on the long-term export survival rather than export entry. The slow-acting disciplining impact of competitive product markets might namely not affect the export entry much. In the model, we thus assume a mid-level manager who is allocated an existing export project and can initiate its termination but is not involved in decisions about entry into exporting.

\subsection{Assumptions and Timing of the Model}

We consider a three period model where a risk-neutral manager takes a decision at time $t=0 \mathrm{in}$ order to maximize her expected utility in periods $t=1$ and $t=2 .^{5}$

$\mathbf{t}=\mathbf{0}$

At time $t=0$, the manager is allocated by her supervisor an ongoing project that represents export of a specific product (we thus use the terms project and product interchangeably). The project is one of two types: efficient (E) with probability $\lambda \in[0,1]$ or inefficient (I) with probability $(1-\lambda)$. Efficient projects are exports of products that correspond to the comparative advantage of the exporting country, while inefficient ones do not. The extent of the export project's inefficiency is captured by the exported product's distance to the comparative advantage, $d \in[0,1)$. Defining $d^{i}, i=\{E, I\}$ as the distance to comparative advantage of a type $i$ project thus implies $d^{E}=0$ and $0<d^{I}<1$. The manager observes the type of the project and decides between pursuing the originally assigned project or initiating its termination and a reassignment to another ongoing

\footnotetext{
${ }^{4}$ Economists since Smith (1776) and Hicks (1935) have argued that competition in product markets is an important source of discipline, ensuring that firms and individuals make the best possible use of the resources at their disposal. Other contributions stressing the disciplining impact of product markets include Leibenstein (1966), Machlup (1967), Winter (1971), Hart (1983), Nickell (1996), Schmidt (1997), Raith (2003) or Giroud and Mueller (2010, 2011). Various papers examine external debt as additional incentive mechanism for self-interested managers (Stiglitz, 1974; Jensen and Meckling, 1976; Grossman and Hart, 1982; Jensen, 1986; Stulz, 1990; Hart and Moore, 1995; Zwiebel, 1996; Lang, Ofek, and Stulz, 1996).

${ }^{5}$ The utility maximization of a risk-neutral manager amounts to the maximizing of her expected perks in the two periods. Assuming a risk-averse manager with a concave rather than linear utility function would not materially affect the implications of the model.
} 
project. The manager knows that a reassigned project will again be efficient (E) with probability $\lambda \in[0,1]$ or inefficient $(\mathrm{I})$ with probability $(1-\lambda)$.

An efficiency-maximizing manager would always initiate termination of a type $I$ project. However, the manager in our model maximizes her own export-driven perks $(X)$, with both efficient and inefficient projects generating the same level of these perks. ${ }^{6}$ Moreover, initiating termination of an ongoing export project imposes costs on the manager that we assume to be equal to a fraction of her perks $(k X$, with $0<k<1)$. We can interpret $k$ as additional effort on the part of manager (convincing the manager's superior about the necessity of altering firm's export portfolio, dealing with corporate procedures associated with terminating an ongoing project, etc.), which disturbs the managerial "quiet life" (Bertrand and Mullainathan, 2003). Alternatively, $k$ can be seen as the probability that manager fails to achieve reassignment to another export project and loses her perks.

$\mathbf{t}=\mathbf{1}$

In the first period $(t=1)$, the manager has to secure external funding from a bank for either the originally assigned export project or the project to which she was reassigned. ${ }^{7}$ With probability $\phi$ the bank funding is secured, the export project remains active, and the manager receives her perks $X$ in the first period. With probability $(1-\phi)$ the bank refuses, export project gets terminated, and the manager does not receive any perks.

The level of financial development $(f)$ in the manager's country affects the probability of obtaining bank funding $\phi$ in two ways. A more developed banking system implies a better availability of external finance to the real economy, which ceteris paribus increases the probability of any given export project to receive bank funding $\left(\frac{\partial \phi(.)}{\partial f}>0\right)$. At the same time, banks in more financially developed countries possess better monitoring and screening skills. This implies a disproportionately lower probability of obtaining bank funding for exports characterized by large distance to the comparative advantage $d$ in countries at a high level of financial development $f\left(\frac{\partial^{2} \phi(.)}{\partial d \partial f}<0\right) .^{8}$

\footnotetext{
${ }^{6}$ We interpret managerial export perks broadly, including the well-documented wage premium and better working conditions offered by the exporting firms (e.g., Bernard and Jensen, 1995; Verhoogen, 2008; Frias, Kaplan, and Verhoogen, 2009; Brambilla, Lederman, and Porto, 2010), which can partially persist even after a switch to another employer. In particular, Mion and Opromolla (2011) find a 15\% wage premium for managers who have previously worked for an exporting firm. Managing export projects also involves non-monetary rewards like travelling abroad or spending time in luxury hotels. All these perks and benefits provide incentives for managers to keep alive even exports that they know are not efficient.

${ }^{7}$ For example, the manager needs to request a renewal of an existing line of credit or attempt to secure another form of trade finance provided by the banking sector like letter of credit, factoring services or bank guarantee.

${ }^{8}$ Diamond (1984) shows how banks can overcome the problem of weak incentives of dispersed securities holders to monitor the firms. Fama (1985) argues that banks are well placed to provide monitoring due to their privileged access to firms' internal information. And Stiglitz and Weiss (1983) document that bank loans can provide the right incentives to managers even if banks cannot directly observe the chosen project.
} 
In the second period $(t=2)$, that can be seen as a proxy for "long term", the project that secured bank funding either succeeds (with probability $\mu$ ) or fails (with probability of $1-\mu$ ) in a competitive destination market. In the former case, the manager receives $X$ also in the second period. In the latter case, she receives in the second period a fraction of her perks $l X$, with $0<l<1$. This fraction can be thought of as, for example, a wage premium in a future job associated with having prior "exporting experience" on her CV (Mion and Opromolla, 2011).

The probability of project's success in a competitive destination market $\mu$ depends on the efficiency of the project. Formally, let $\mu_{i}=\left\{\mu_{I}, \mu_{E}\right\}$ be the success probability of a project of type $i(i \in I, E)$ in a competitive destination market, with $0 \leq \mu_{I}<\mu_{E} \leq 1$. All projects corresponding to comparative advantage are assumed to share the same probability of export success $\mu_{E} \cdot{ }^{9}$ The probability of export success for the inefficient projects decreases in the extent of the inefficiency, i.e. in the distance to comparative advantage $\left(\frac{\partial \mu_{I}(.)}{\partial d}<0\right)$.

\subsection{Managerial Decision}

The manager knows all the parameters of the model $\left(d, f, l, k, \mu_{E}, \lambda\right)$. She is also aware of the level of competitive pressures faced by the inefficient projects in the destination market $\left(\frac{\partial \mu_{I}(.)}{\partial d}\right)$ as well as of the availability of external finance and monitoring skills of the banks in her country and their impact on the probability of securing bank funding $\left(\frac{\partial \phi(.)}{\partial f}, \frac{\partial^{2} \phi(.)}{\partial d \partial f}\right)$. Taking as given these external constraints in her pursuit of maximizing export perks, the manager decides at time $t=0$ whether to initiate termination of an inefficient project. ${ }^{10,11}$

The utility of the manager if she continues $(\mathrm{C})$ with an inefficient export project writes:

$$
U^{C}=\phi(d, f)\left\{X+\mu_{I}(d) X+\left[1-\mu_{I}(d)\right] l X\right\}
$$

\footnotetext{
${ }^{9}$ In a frictionless Heckscher-Ohlin world (with complete frictionless markets, no tariffs, zero transportation costs, etc.), the projects perfectly aligned with the comparative advantage of the exporting country would always survive in the destination market $\left(\mu_{E}=1\right)$.

10 The manager will never attempt to terminate an efficient project. She would namely need to pay the cost $k X$ just to be reassigned to another ongoing project that is associated with the same level of perks $X$ and faces the same (with probability $\lambda$ ) or even lower (with probability $1-\lambda$ ) chances of generating those perks over the two periods. Similarly, the manager will never find it optimal to initiate termination of an inefficient project and pay the costs $k X$ after obtaining bank funding at time $t=1$ if she did not find it optimal already at time $t=0$ before securing the funding.

${ }^{11}$ As mentioned before, the model deliberately does not deal with the issue of export entry. In particular, the "switching" costs $k$ (effort needed to terminate an already existing project, uncertain reassignment to another ongoing project, etc.) do not apply when it comes to new export projects while effort related to export entry arguably does not differ across efficient and inefficient projects. The manager would therefore always prefer to enter the export market with an efficient project that is more likely to sustain the competitive pressures and thus generate export perks in the long term. Following the same logic, the export entry would be also efficient if we interpreted our model in a broader sense where the manager could initiate a new export project instead of pursuing reassignment to another ongoing project.
} 
where $\phi(d, f)$ is the probability of obtaining bank funding for an inefficient project and the expression in curled brackets represents the expected managerial perks in the first and second period.

Manager's utility in case of initiating termination $(\mathrm{T})$ of an inefficient project and pursuing reassignment to an efficient one writes:

$$
U^{T}=\lambda \phi(0, f)\left\{X+\mu_{E} X+\left[1-\mu_{E}\right] l X\right\}+[1-\lambda] \phi(d, f)\left\{X+\mu_{I}(d) X+\left[1-\mu_{I}(d)\right] l X\right\}-k X
$$

where $\phi(0, f)$ is the probability of obtaining bank funding for an efficient project with zero distance to comparative advantage and $\lambda$ is the probability of being reassigned to such project after initiating the termination of the originally allocated export project. The first set of curled brackets captures the expected perks if the manager succeeds in being reassigned to an efficient project while the second set of curled brackets represents the perks in case of reassignment to an inefficient project.

The manager maximizes her own utility so that: $U_{\text {manager }}=\operatorname{Max}\left\{U^{T}, U^{C}\right\}$. She will thus initiate termination of a project that does not correspond to the comparative advantage if and only if: ${ }^{12}$

$$
\begin{gathered}
U^{T}-U^{C} \geqslant 0 \\
\lambda \phi(0, f)\left\{X+\mu_{E} X+\left[1-\mu_{E}\right] l X\right\}-\lambda \phi(d, f)\left\{X+\mu_{I}(d) X+\left[1-\mu_{I}(d)\right] l X\right\}-k X \geqslant 0 \\
\phi(0, f)\left\{1+\mu_{E}+\left[1-\mu_{E}\right] l\right\}-\phi(d, f)\left\{1+\mu_{I}(d)+\left[1-\mu_{I}(d)\right] l\right\} \geqslant \frac{k}{\lambda}
\end{gathered}
$$

The right-hand side (RHS) of Equation (5) represents the cost of terminating an inefficient export project from the point of view of self-interested manager. This cost is increasing in the share of perks lost by initiating the termination of an inefficient project $(k)$ and decreasing in the probability of being reassigned to an efficient project $(\lambda)$.

The left-hand side (LHS) of Equation (5) represents the benefit for the manager from terminating an inefficient project. This benefit increases with the exported product's distance to the comparative advantage $d$. Formally, the derivative of the LHS with respect to $d$ is positive:

\footnotetext{
${ }^{12}$ We assume that if indifferent $\left(U_{T}=U_{C}\right)$, the manager will do the "right thing" and initiate the termination of an inefficient project.
} 


$$
-\underbrace{\frac{\partial \phi(d, f)}{\partial d}}_{\leq 0}\left\{1+\mu_{I}(d)+\left[1-\mu_{I}(d)\right] l\right\}-\phi(d, f) \underbrace{\frac{\partial \mu_{I}(d)}{\partial d}}_{<0}[1-l]>0
$$

The intuition is as follows. The further away the project is from the comparative advantage, the less likely it will survive the product market competition in the destination country $\left(\frac{\partial \mu_{I}(d)}{\partial d}<0\right)$, depriving the manager of the $[1-l]$ fraction of her perks in the second period for a project that has received external funding (which happens with probability $\phi$ ). This mechanism captured by the second term determines also the sign of the whole expression, under the plausible assumption that the extent of inefficiency of export projects does not increase the probability of obtaining external funding $\left(\frac{\partial \phi(d, f)}{\partial d} \leq 0\right)$.

The incentive impact of product market competition in the destination country is further reinforced by the banking development in the country of origin. Formally, the second derivative of the LHS of Equation (5) with respect to distance to comparative advantage $d$ and financial development $f$ is also positive:

$$
-\underbrace{\frac{\partial^{2} \phi(d, f)}{\partial d \partial f}}_{<0}\left\{1+\mu_{I}(d)+\left[1-\mu_{I}(d)\right] l\right\}-[1-l] \underbrace{\frac{\partial \phi(d, f)}{\partial f}}_{>0} \underbrace{\frac{\partial \mu_{I}(d)}{\partial d}}_{<0}>0
$$

The intuition for this result is as follows. The disciplining impact of a competitive destination market on export success and the related managerial perks is less relevant if projects fail indiscriminately due to the lack of bank funding. The financial development increases the probability of export projects to receive such funding (the external finance availability channel, $\frac{\partial \phi(d, f)}{\partial f}>0$ ) so that the ultimate success or failure of an export project is increasingly determined by its alignment with comparative advantage, reinforcing the incentive effect of the product market competition $\left(\frac{\partial \mu_{I}(d)}{\partial d}<0\right)$. The overall effect is even stronger if a more developed banking sector possess better monitoring and screening skills so that the additional funds get channeled disproportionately towards export projects closer to the comparative advantage of the exporting country (the bank monitoring channel, $\left.\frac{\partial^{2} \phi(d, f)}{\partial d \partial f}<0\right) \cdot{ }^{13}$

Equations (6) and (7) capture the idea that product market competition in the destination country provides incentives for perks-maximizing managers to initiate termination of inefficient ex-

\footnotetext{
${ }^{13}$ As for the direct impact of financial development on the managerial benefit of initiating termination of an inefficient project, the derivative of the LHS of Equation (5) with respect to $f$ has an ambiguous sign: $\frac{\partial \phi(0, f)}{\partial f}\left\{1+\mu_{E}+[1-\right.$ $\left.\left.\mu_{E}\right] l\right\}-\frac{\partial \phi(d, f)}{\partial f}\left\{1+\mu_{I}(d)+\left[1-\mu_{I}(d)\right] l\right\} \gtreqless 0 \quad$ This is due to the fact that better access to external funding improves the probability of obtaining bank funding for both efficient and inefficient projects $\left(\frac{\partial \phi(0, f)}{\partial f}>0, \frac{\partial \phi(d, f)}{\partial f}>0\right)$.
} 
port projects and that this incentive effect of product market competition is amplified in exporting countries with a well-developed banking sector. The model can thus provide a simple motivation for the empirical part of our paper that tests the following two hypotheses:

H1: The probability of terminating an ongoing export spell of a given product into a competitive destination market increases with the distance of this product to the comparative advantage of the exporting country.

H2: This disciplining impact of distance to comparative advantage is magnified by the level of banking development in the exporting country.

The phrasing in both the model and in hypothesis $\mathrm{H} 2$ stresses the disciplining impact of the banking sector. Stock and bond markets could be in principle also a source of financing for export projects and thus reinforce the disciplining impact of the product markets via the external finance availability channel $\left(\frac{\partial \phi(d, f)}{\partial f}>0\right) \cdot{ }^{14}$ Making the standard assumption about superior monitoring abilities of banks (e.g., based on arguments by Diamond, 1984 or Fama, 1985), the presence of the monitoring channel $\left(\frac{\partial^{2} \phi(d, f)}{\partial d \partial f}<0\right)$ in Equation (7) should nevertheless lead to more robust results for the banking sector as opposed to the stock and bond markets. Our empirical results using various proxies for the strength of banks, stock and bond markets in the exporting countries will confirm this conjecture.

\section{Data}

Our unit of analysis is an export spell defined as the length (in years) that a country $c$ exports a particular good $k$ defined at the HS-6 digit level to the USA without interruption. Let $z(c k)$ denote an export spell of product $k$ exported from country $c$ to the USA. Furthermore, let $t_{z}$ be the spell initiation year, i.e., the first year in which the export spell is active. As the initiation year is spell-specific, indexing observations by initiation year eliminates the need to index them by spell. Note that there can be multiple spells for a given country-product pair. ${ }^{15}$ The unit of observation is thus an (exporting country)*product*(initiation year) triplet. All time-varying explanatory variables are measured at the time $t_{z}$.

\footnotetext{
${ }^{14}$ In practice, banks are the principal suppliers of export financing (Amiti and Weinstein, 2011). Bank lending also clearly dominates debt financing around the world (Shleifer and Vishny, 1997).

${ }^{15}$ For instance, if a country exports a given product to the USA during ten years starting in 1992, we take this as one spell with a length of 10 years and initiation year 1992. If a country exports a given product to the USA during 1995-1998 and then again during 2000-2005, we treat these as two independent spells of 4 and 6 years with initiation years of 1995 and 2000, respectively.
} 


\subsection{Financial Variables}

We use several variables measuring the strength of financial markets and institutions in the exporting country. As our main proxy for the strength of the banking sector, we use the ratio of the bank credit to private sector over the country's GDP $\left(B C_{c, t_{z}}\right)$. The ratio of the stock market capitalization over the GDP $\left(S t M_{c, t_{z}}\right)$ captures the depth of stock markets in the exporting country. Both variables are the standard proxies for the strength of banks and stock markets in a given country (see, e.g., Strieborny and Kukenova, 2016).

We also use various alternative measures to test the robustness of our results. In the case of banks, these measures include bank assets $\left(B A_{c, t_{z}}\right)$, total credit $\left(T C_{c, t_{z}}\right)$, non-bank credit $\left(N B C_{c, t_{z}}\right)$, and credit to government $\left(G C_{c, t_{z}}\right)$. Bank assets are claims on domestic real nonfinancial sector by deposit money banks as a share of GDP, total credit is the ratio of private credit by deposit money banks and other financial institutions over GDP, non-bank credit is the credit extended by other financial institutions than banks as a share of GDP (i.e., the difference between values for total credit and bank credit), credit to government is the credit extended to the general government sector, including central, state and local governments and social security funds. In the case of stock markets, the alternative measures are stock market value traded $\left(S t M V T_{c, t_{z}}\right)$ and stock market turnover $\left(S t M T_{c, t_{z}}\right)$. Stock market value traded is the value of stock market transactions relative to GDP and stock market turnover is the ratio of the value of total shares traded to market capitalization.

We use three proxies for the strength and development of bond markets. Domestic private bonds $\left(D P B_{c, t_{z}}\right)$ is the ratio of outstanding domestic private debt securities over GDP while the proxy called international private bonds $\left(I P B_{c, t_{z}}\right)$ represents the ratio of outstanding international private debt securities over GDP. The third proxy, non-financial international bonds $\left(N F I B_{c, t_{z}}\right)$, captures the ratio of international corporate bonds issued by non-financial firms to GDP.

The data are from the Global Financial Development Database that builds on the earlier work by Beck, Demirgüç-Kunt, and Levine (2000) and has been substantially extended by Cihak et al. (2012). The database contains various indicators of financial development across countries and over time and is regularly updated. The exception is the variable non-financial international bonds $\left(N F I B_{c, t_{z}}\right)$ that comes from the statistics compiled by the Bank for International Settlements (BIS). All financial variables measured at the exporting country level enter the regressions both directly $\left(B C_{c, t_{z}}, S t M_{c, t_{z}}\right.$, etc. $)$ and interacted with our product-country measure of distance to comparative advantage $\left(B C_{c, t_{z}} * D C A_{c k, t_{z}}, S t M_{c, t_{z}} * D C A_{c k, t_{z}}\right.$, etc. $)$. 
According to a long-standing idea within the Heckscher-Ohlin theoretical framework, international trade in multiple commodities can be explained by a "product chain of comparative advantage" that ranks the products in order of their factor intensities (Jones, 1956-57; Bhagwati, 1972). In the context of multiple products and multiple countries, countries are arranged along the product chain in accordance with their relative factor endowments, with each country exporting the products within its own segment and importing all the others (Deardorff, 1979). Each country thus specializes in exporting products whose relative factor intensity broadly corresponds to the relative factor endowment of this country. ${ }^{16}$ In the Heckscher-Ohlin framework, the "distance to comparative advantage" thus captures the extent of discrepancy between each product's revealed factor intensity and each country's factor endowment.

This approach should be seen as complementary to recent literature on the alternative Ricardian theory that stresses technology rather than factor endowments as a possible source of comparative advantage in international trade (see, e.g., Dornbusch, Fischer, and Samuelson, 1977; Eaton and Kortum, 2002; Costinot, 2009; Costinot, Donaldson, and Komunjer, 2012). ${ }^{17}$ Our focus on factor endowments as the main source of comparative advantage is a pragmatic decision motivated by data availability at a highly disaggregated level in a broad cross-country setting. ${ }^{18}$ Moreover, Morrow (2010) shows that omitting Ricardian forces do not bias tests of the Heckscher-Ohlin model while ignoring Heckscher-Ohlin forces can lead to biased tests of the Ricardian model. ${ }^{19}$

\subsection{Distance to Comparative Advantage - Measurement}

The specific measure of distance to comparative advantage $(D C A)$ used in our paper has been developed by Cadot, Carrère, and Strauss-Kahn (2011). It is computed at the 6-digit level of the HS classification and compares in a given year the revealed factor intensity of a given product with the factor endowment of a given country. A large distance to comparative advantage thus identifies

\footnotetext{
${ }^{16}$ Like in the two-country case, this reasoning is valid only if factor price equalization does not hold and the world is thus divided into multiple diversification cones. In Heckscher-Ohlin framework with more products than production factors, equalization of factor prices would namely lead to indeterminacy of both production and trade (see also Dornbusch, Fischer, and Samuelson, 1980). More recent papers on diversification cones include Schott (2003, 2004) and Xiang (2007).

17 Some scholars suggest the different dimensions of institutional quality as another possible source of comparative advantage. Nunn and Trefler (2014) provide a thorough overview of this literature.

18 Costinot, Donaldson, and Komunjer (2012) provide a modern interpretation of the revealed comparative advantage in the context of the Ricardian theory, testing it in a sample of 21 rich and middle-income countries and 13 broadly defined industries.

19 To be fair, Morrow (2010) himself calls the evidence about potential bias in empirical work focusing on Ricardian comparative advantage "weak and mixed". Costinot, Donaldson, and Komunjer (2012) show evidence for the orthogonality of Ricardian and Heckscher-Ohlin motives in their data, although this is not the main focus of their paper.
} 
products that represent inefficient exports as they use up scarce rather than abundant resources in a given economy. Specifically, the formula for the Euclidean distance of product $k$ from the comparative advantage of country $c$, in the initiation year $t_{z}$ of export spell $z$, writes:

$$
D C A_{c k, t_{z}}=\sqrt{\operatorname{std}\left(\kappa_{c, t_{z}}-\hat{\kappa}_{k, t_{z}}\right)^{2}+\operatorname{std}\left(h_{c, t_{z}}-\hat{h}_{k, t_{z}}\right)^{2}}
$$

where $\kappa_{c, t_{z}}$ and $h_{c, t_{z}}$ are the endowments in physical and human capital of country $c$, and $\hat{\kappa}_{k, t_{z}}$ and $\hat{h}_{k, t_{z}}$ are the corresponding revealed factor intensities of product $k$, all in log terms and measured in the initiation year $t_{z}$ of the export spell $z$. In one of the robustness tests, we will extend the two-factor framework of distance to comparative advantage and consider also the role of natural resources by adding arable land per worker as a third production factor. Since $\kappa$ and $h$ are measured in different units, we use normalized differences between product factor intensities and country factor endowments with mean 0 and standard deviation 1 ("std" in the formula above stands for "standardized"). This ensures that physical and human capital are given equal weights in the overall distance formula. ${ }^{20}$

The data on national factor endowments are from Cadot, Tumurchudur, and Shirotori (2009). In a given year, the stock of physical capital per worker in a given country $(\kappa)$ is constructed according to the perpetual inventory method. Human capital per worker $(h)$ is calculated from the average years of schooling in a given country using attainment data. The product revealed factor intensities are from Cadot, Tumurchudur, and Shirotori (2009). They are calculated as weighted averages of the factor endowments of the countries exporting a given product, following the methodology introduced by Hausmann, Hwang, and Rodrik (2007). Specifically, the revealed physical capital intensity of product $k$ in year $t_{z}$ is calculated as:

$$
\hat{\kappa}_{k, t_{z}}=\sum_{c} \omega_{c k, t_{z}} \kappa_{c, t_{z}}
$$

where $\kappa_{c, t_{z}}$ is country $c$ 's endowment in physical capital at time $t_{z}$, and the weights are given by $\omega_{c k, t_{z}}=\frac{X_{c k, t_{z}} / X_{c, t_{z}}}{\sum_{c} X_{c k, t_{z}} / X_{c, t_{z}}}$, with $X$ denoting export values. These weights correspond to the revealed comparative advantage of country $c$ in product $k$. The numerator in the formula for $\omega_{c k, t_{z}}$ measures the importance of product $k$ in the overall exports of country $c$. The denominator aggregates the export shares of product $k$ across all countries. Weighting countries' factor endowments by the revealed comparative advantage rather than by the simple export shares allows us to account for distortions due to differences in countries' size (Hausmann, Hwang, and Rodrik, 2007 and Cadot,

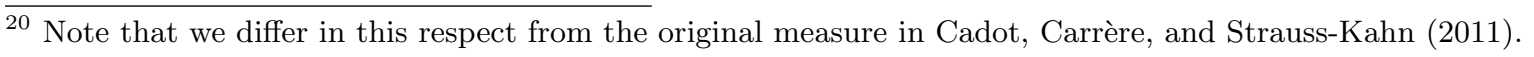


Tumurchudur, and Shirotori, 2009 provide numerical examples). ${ }^{21}$ Similarly, the revealed human capital intensity of product $k$ is calculated as:

$$
\hat{h}_{k, t_{z}}=\sum_{c} \omega_{c k, t_{z}} h_{c, t_{z}}
$$

where $h_{c, t_{z}}$ is endowment in human capital of country $c$ at time $t_{z}$.

\subsection{Other Variables}

Product-level trade variables: The export survival rate in the US market and all trade-related control variables at the product level (initial export, total export, number of suppliers, multiple spell dummy) are computed using the BACI dataset developed by the CEPII and described in Gaulier and Zignago (2010). The dataset provides harmonized bilateral trade flows for more than 5,000 HS 6-digit products and 143 countries. Export flows are reported annually in values (thousands of US dollars) and quantities. ${ }^{22}$ Trade data at the HS 6-digit level is particularly fitting for survival analysis. It allows us to account for export failures at a detailed product level which would otherwise be undetected when using more aggregated industry data. In our estimations, we focus on the manufacturing exports to the USA from the 1995-2005 period. We start our sample period in 1995 due to the high number of missing values before $1994 .{ }^{23}$ We finish our sample period in 2005 in order to avoid possible spurious correlations due to the recent global financial crisis that effected both our empirical proxies for the strength of banks, bond and stock markets and the functioning of international trade in manufacturing goods. We plan to examine the issue of interactions between financial shocks and crises and product market discipline in later research.

Macroeconomic variables: Real exchange rate is the nominal effective exchange rate (a measure of the value of a currency against a weighted average of several foreign currencies) divided by a price deflator or index of costs. The source is the World Development Indicators of the World Bank. The annual data for the GDP per capita measured in log terms $\left(G D P p c_{c, t_{z}}\right)$ are taken from the World Development Indicator Report 2006 and are reported in constant 2000 US dollars. Both macroeconomic variables measured at the exporting country level enter the regressions directly

\footnotetext{
${ }^{21}$ The formulation of $\omega_{c k, t_{z}}$ used by Hausmann, Hwang, and Rodrik (2007) and Cadot, Tumurchudur, and Shirotori (2009) slightly differs from the original index of revealed comparative advantage by Balassa (1965). This modified formulation ensures that the weights add up to one: $\sum_{c} \omega_{c k, t_{z}}=\sum_{c} \frac{X_{c k, t_{z}} / X_{c, t_{z}}}{\sum_{c} X_{c k, t_{z}} / X_{c, t_{z}}}=\frac{\sum_{c} X_{c k, t_{z}} / X_{c, t_{z}}}{\sum_{c} X_{c k, t_{z}} / X_{c, t_{z}}}=1$

${ }^{22}$ We do not need export values for measuring the export survival rate but we do use them for constructing some trade-related control variables and the dependent variable in one of the robustness tests.

${ }^{23}$ In particular, we are using BACI in HS classification from 1992 that covers the period 1994-2005. As the survival analysis relies on the length of export spells, we cannot use the data from the initial year. This leaves us with the data for 1995-2005.
} 
$\left(R E R_{c, t_{z}}, G D P p c_{c, t_{z}}\right)$ as well as interacted with our measure of distance to comparative advantage $\left(R E R_{c, t_{z}} * D C A_{c k, t_{z}}, G D P p c_{c, t_{z}} * D C A_{c k, t_{z}}\right)$.

Industry-level variables: Let $j$ denote an industry. External finance dependence at the level of ISIC 4-digit sectors comes from Raddatz (2006) and is based on financial data about US firms from Compustat. In particular, the dependence on external finance of industry $j\left(E x F_{j}\right)$ is defined as capital expenditures minus cash flow from operations, divided by capital expenditures, for the median firm in that industry. Human capital intensity $\left(\right.$ HumInt $\left._{j}\right)$ and physical capital intensity $\left(\right.$ CapInt $\left._{j}\right)$ for ISIC 3-digit sectors come from Braun (2003) and have already been used in trade literature (Manova, 2008, 2013). ${ }^{24,25}$ All industry characteristics $\left(E x F_{j}\right.$, CapInt $_{j}$, HumInt $\left._{j}\right)$ are computed solely from the US data and thus do not vary across exporting countries. The US market is large, diversified, well-functioning, and comparatively frictionless. Industry characteristics based on the US data can thus be interpreted as exogenous technological characteristics that are not driven by various market imperfections prevalent in many countries. This idea comes back to the seminal paper of Rajan and Zingales (1998). ${ }^{26}$

Table I shows descriptive statistics for the main variables used in our analysis. When controlling for all variables of interest, our final database consists of 191,078 export spells of 4,562 HS 6-digit products from 71 exporting countries to the USA over the period 1995-2005. Appendix B gives the list of countries in our sample.

Table II provides some preliminary evidence on the relationship between export survival, finance, and comparative advantage. Products that are closer to the comparative advantage of the exporting countries seem to face better survival odds in the US destination market. The average length of export spells with initial value of distance to comparative advantage $D C A_{c k, t_{z}}$ below the 25th percentile is 5.05 years while the average length for export spells with initial value of $D C A_{c k, t_{z}}$ above the 75 th percentile is 4.00 years. The corresponding median values are 3 and 2 years, respectively. A strong domestic banking sector in the exporting country (initial value of $B C_{c, t_{z}}$ above the 75 th percentile versus below the 25 th percentile) also seems to improve products' survival chances on the US market (average spell lengths of 5.60 years versus 3.57 years and median spell lengths of 4 versus 2 years). Well-developed stock markets seem to play quantitatively

\footnotetext{
${ }^{24}$ Dependence on external finance as well as strata effects in our econometric analysis are defined at the finer 4-digit level of the ISIC classification. In the text, we therefore generally refer to $j$ as denoting ISIC 4-digit industry.

${ }^{25}$ Romalis (2004) uses US SIC classification instead.

${ }^{26}$ Our product-level variables are at the HS 6-digit level and there is no direct concordance between the industrylevel ISIC 4-digit Revision 2 classification and the product-level HS classification. In order to match the data, we therefore first apply the concordance between ISIC Revision 2 and ISIC Revision 3 classification and then the concordance between the latter and the HS 6-digit classification.
} 
a somewhat lesser role (5.13 years versus 4.10 years in case of average spell lengths and 3 versus 2 years in case of median spell lengths). However, these prima-facie differences do not control for export spells heterogeneity and are subject to potential confounding influences. Next section thus turns to a systematic exploration of the disciplining effect of product markets and finance on countries' export composition within a formal econometric framework.

Table I: Summary Statistics: Data

\begin{tabular}{|c|c|c|c|c|c|}
\hline Variable & Obs. & Mean & Std. Dev. & Min & Max \\
\hline Distance to comparative advantage, $\left(D C A_{c k, t_{z}}\right)$ & 191078 & 1.18 & 0.79 & 0 & 6.64 \\
\hline Banks, $\left(B C_{c, t_{z}}\right)$ & 191078 & 0.61 & 0.46 & 0.03 & 2.18 \\
\hline Stock markets, $\left(S t M_{c, t_{z}}\right)$ & 175481 & 0.50 & 0.46 & 0.01 & 3.03 \\
\hline GDP per capita, $\left(G D P p c_{c, t_{z}}\right)$ & 191078 & 9.16 & 0.94 & 6.29 & 10.47 \\
\hline Dependence on external finance, $\left(E x F_{j}\right)$ & 191078 & 0.25 & 0.29 & -0.55 & 1.26 \\
\hline Banks x dist. to comp. adv., $\left(B C_{c, t_{z}} * D C A_{c k, t_{z}}\right)$ & 191078 & 0.69 & 0.75 & 0 & 12.09 \\
\hline Stock markets $\mathrm{x}$ dist. to comp. advantage, $\left(S t M_{c, t_{z}} * D C A_{c k, t_{z}}\right)$ & 175481 & 0.54 & 0.70 & 0 & 14.71 \\
\hline GDPpc $\mathrm{x}$ dist. to comp. advantage, $\left(G D P p c_{c, t_{z}} * D C A_{c k, t_{z}}\right)$ & 191078 & 10.65 & 6.73 & 0.01 & 69.00 \\
\hline Banks x dep. on ext. finance, $\left(B C_{c, t_{z}} * E x F_{j}\right)$ & 191078 & 0.15 & 0.25 & -1.19 & 2.74 \\
\hline Stock markets x dep. on ext. finance, $\left(S t M_{c, t_{z}} * E x F_{j}\right)$ & 175481 & 0.12 & 0.22 & -1.65 & 3.82 \\
\hline Bank assets, $\left(B A_{c, t_{z}}\right)$ & 191078 & 0.70 & 0.47 & 0.04 & 2.48 \\
\hline Total credit, $\left(T C_{c, t_{z}}\right)$ & 191078 & 0.63 & 0.44 & 0.03 & 2.28 \\
\hline Non-bank credit, $\left(N B C_{c, t_{z}}\right)$ & 191078 & 0.02 & 0.19 & -1.19 & 0.83 \\
\hline Credit to government, $\left(G C_{c, t_{z}}\right)$ & 54329 & 51.91 & 24.66 & 6.90 & 143.80 \\
\hline Stock market value traded, $\left(S t M V T_{c, t_{z}}\right)$ & 173368 & 0.27 & 0.34 & 0.00 & 2.00 \\
\hline Stock market turnover, $\left(S t M T_{c, t_{z}}\right)$ & 172200 & 0.56 & 0.60 & 0.00 & 5.12 \\
\hline Domestic private bonds to GDP, $\left(D P B_{c, t_{z}}\right)$ & 127,260 & 0.23 & 0.22 & 0.00 & 1.42 \\
\hline International private bonds to GDP, $\left(I P B_{c, t_{z}}\right)$ & 158,291 & 0.09 & 0.09 & 0.00 & 0.92 \\
\hline Non financial international bonds to GDP, $\left(N F I B_{c, t_{z}}\right)$ & 168,113 & 0.02 & 0.03 & 0.00 & 0.16 \\
\hline Real exchange rate, $\left(R E R_{c, t_{z}}\right)$ & 129642 & -2.23 & 0.02 & -2.31 & -2.10 \\
\hline Average export growth & 191078 & 0.02 & 0.44 & -7.25 & 5.23 \\
\hline Physical capital, $\left(\kappa_{c, t_{z}}\right)$ & 191078 & 10.50 & 1.17 & 6.35 & 12.09 \\
\hline Human capital, $\left(h_{c, t_{z}}\right)$ & 191078 & 7.24 & 2.56 & 0.69 & 11.89 \\
\hline Physical capital intensity, $\left(\right.$ CapInt $\left._{j}\right)$ & 191078 & 0.06 & 0.02 & 0.02 & 0.20 \\
\hline Human capital intensity, $\left(\right.$ HumInt $\left._{j}\right)$ & 191078 & 0.95 & 0.24 & 0.50 & 1.66 \\
\hline Physical capital x phys. cap. intensity, $\left(\kappa_{c, t_{z}} *\right.$ CapInt $\left._{j}\right)$ & 191078 & 0.67 & 0.27 & 0.12 & 2.36 \\
\hline Human capital $\mathrm{x}$ hum. cap. intensity, $\left(h_{c, t_{z}} * H_{u m I n t_{j}}\right)$ & 191078 & 6.90 & 3.10 & 0.34 & 19.67 \\
\hline Initial export, $\left(\right.$ initial_export $\left._{c k, t_{z}}\right)$ & 191078 & 10.12 & 2.64 & 0.00 & 23.72 \\
\hline Total export, $\left(\right.$ total_export $\left._{c k, t_{z}}\right)$ & 191078 & 13.00 & 2.83 & 0.00 & 24.07 \\
\hline Number of suppliers, (NSupplier $s_{k, t_{z}}$ ) & 191078 & 37.07 & 19.09 & 1.00 & 136 \\
\hline Multiple spell, $\left(\right.$ multiple $_{s}$ pell $\left._{c k}\right)$ & 191078 & 0.58 & 0.49 & 0.00 & 1.00 \\
\hline \multicolumn{6}{|l|}{ Alternative measures of distance to comparative advantage } \\
\hline Absolute distance & 191078 & 1.60 & 1.12 & 0.00 & 9.20 \\
\hline Euclidean distance, incl. land per worker & 191078 & 1.54 & 0.80 & 0.02 & 7.26 \\
\hline Absolute distance, incl. land per worker & 191078 & 2.39 & 1.28 & 0.03 & 12.18 \\
\hline Euclidean distance, excl. origin country & 190490 & 1.18 & 0.79 & 0.00 & 6.58 \\
\hline Absolute distance, excl. origin country & 190490 & 1.60 & 1.11 & 0.01 & 9.12 \\
\hline Euclidean distance, excl. USA as destination country & 191078 & 1.18 & 0.79 & 0.00 & 6.64 \\
\hline Absolute distance, excl. USA as destination country & 191078 & 1.60 & 1.12 & 0.00 & 9.19 \\
\hline
\end{tabular}

Table II: Summary Statistics: Export Spells

\begin{tabular}{|c|c|c|c|}
\hline & \# Spells & Mean spell length & Median spell length \\
\hline Full sample & 191078 & 4.79 & 3 \\
\hline$D C A_{c k, t_{z}}<25$ th percentile & 47769 & 5.05 & 3 \\
\hline$D C A_{c k, t_{z}}>75$ th percentile & 47769 & 4.00 & 2 \\
\hline$B C_{c, t_{z}}<25$ th percentile & 47733 & 3.57 & 2 \\
\hline$B C_{c, t_{z}}>75$ th percentile & 47735 & 5.60 & 4 \\
\hline$S t M_{c, t_{z}}<25$ th percentile & 43766 & 4.10 & 2 \\
\hline$S t M_{c, t_{z}}>75$ th percentile & 43729 & 5.13 & 3 \\
\hline
\end{tabular}




\section{Empirical Strategy}

The difference-in-difference approach in this paper relies on exploiting the varying strength of the competitive pressures a given product faces in the US destination market and the varying strength of financial markets and institutions in the countries exporting these products to the USA. Our focus on a single destination market filters out potential confounding influences arising from the destination-markets heterogeneity. The use of bilateral trade data thus allows us a cleaner distinction between the impact of financial development measured at the level of exporting countries and the competitive pressures in the US product market. ${ }^{27}$ We choose the United States as our preferred destination market because it represents the largest among the highly competitive product markets of the developed countries. ${ }^{28}$ We will perform robustness tests with alternative destination markets.

We are interested in the long-term survival of the export spells and rely on a formal duration (survival) analysis, where the dependent variable is the hazard rate (hazard function) $h_{c k}(t)$ - the probability that a given product $k$ exported by country $c$ exits the US market at time $t$, conditional on its survival until that time (i.e., conditional on the fact that country $c$ exported the given product $k$ to US continuously for $t$ years, counted from the initiation year $t_{z}$ of the export spell $\left.z\right) .{ }^{29,30}$ This econometric framework thus captures the probability of products' long-term exporting failure, which makes it particularly suitable to maintain our focus on long-term impact of product markets and financial institutions. It is also in accordance with our simple model that centers around an export manager and her decision whether to initiate the termination of an ongoing export project.

We rely on the widely used continuous time proportional hazard model proposed by Cox (1972), henceforth Cox model (see Online Appendix A for further technical details and Kiefer, 1988 for a detailed description of duration analysis). In the Cox model, the hazard function varies from

27 This approach is also in accordance with our model where the intensity of product market competition in the destination market (represented by $\mu_{E}, \mu_{I}, \frac{\partial \mu_{I}(.)}{\partial d}<0$ ) is held constant while the variation in financial development $(f)$ determines the probability of obtaining export financing in a given exporting country and thus affects the incentives of self-interested managers to initiate termination of inefficient exports.

${ }^{28}$ Due to its political and military power, the United States is also well-placed to withstand political pressures from other countries trying to place their products on international markets. For example, Berger et al. (2013) show that successful CIA interventions in foreign countries lead to dramatic export increases from the US to these countries but have no impact on the exports from the affected countries to the US destination market.

${ }^{29}$ Besedes and Prusa (2006a) were the first to apply the analytical tools of survival analysis in the context of international trade, triggering an extensive follow-up research on trade survival (see, e.g., Besedes and Prusa, 2006b; Carballo and Volpe Martincus, 2008; Jaud, Kukenova, and Strieborny, 2009; Nitsch, 2009; Brenton, Saborowski, and von Uexkull, 2010; Obashi, 2010; Besedes and Prusa, 2011; Fugazza and Molina, 2011; Brenton, Cadot, and Pierola, 2012; Carrere, and Strauss-Kahn, 2012; Chen, 2012; Besedes, 2013; Cadot et al., 2013; Jaud, Kukenova, and Strieborny, 2015).

${ }^{30}$ In one of the robustness checks in the Online Appendix, we also run a linear probability model of exiting the US destination market as an alternative to the formal survival framework. 
zero (meaning certain survival at time $t$ ) to infinity (meaning certain failure at time $t$ ) and is defined as a product of two multiplicative terms. The first term is a baseline (underlying) hazard function $h_{0}$ that is function of time alone. The second term is an exponential function containing a set of independent variables that shift the baseline hazard function. An important advantage of the semiparametric Cox model is the fact that the shape of the baseline hazard function is left unspecified so that no distributional assumptions are required. Such assumptions could possibly lead to misspecifications and biased estimates.

\subsection{The Role of Banks}

We start by examining the allocative and selective role of banks. We ask whether these external debtholders enhance the disciplining effect of product markets by pushing the composition of manufacturing exports towards goods congruent with the comparative advantage of the exporting country. Specifically, we regress the hazard rate $h_{c k}(t)$ of a country-product export spell to the US on the following independent variables: the Euclidean distance between the revealed factor intensity of product $k$ and the factor endowment of exporting country $c$ at the initiation of the export spell at time $t_{z}$ (distance to comparative advantage - $D C A_{c k, t_{z}}$ ), an interaction term between the ratio of the bank credit over GDP in exporting country $c$ and our measure of distance to comparative advantage at time $t_{z}\left(B C_{c, t_{z}} * D C A_{c k, t_{z}}\right)$, the bank credit over GDP in exporting country $c\left(B C_{c, t_{z}}\right)$, a vector of control variables $(\mathbf{x})$, as well as a full set of exporting-country fixed effects $\left(\delta_{c}\right)$ and initiation-year fixed effects $\left(\delta_{t_{z}}\right)$. Note that the time dimension in our dataset is reduced to the initiation years and time-varying variables are thus measured at the time $t_{z}$. The unit of analysis is an observation at the (exporting country)* product*(initiation year) level. Our estimation equation focusing on the disciplining impact of banks and product markets thus writes:

$h_{c k}(t)=h_{0, j}(t) \exp \left[\beta_{1} D C A_{c k, t_{z}}+\beta_{2} B C_{c, t_{z}} * D C A_{c k, t_{z}}+\gamma B C_{c, t_{z}}+\mathbf{x}_{c k, t_{z}} \phi+\delta_{c}+\delta_{t_{z}}+\varepsilon_{c k, t_{z}}\right]$

where $\varepsilon_{c k, t_{z}}$ is the error term. Equation 11 is estimated using partial maximum likelihood and standard errors are clustered at the (exporting country)*(initiation year) level $\left(c * t_{z}\right)$. The relationship between the covariates and the hazard rate is log-linear, allowing parameters to be interpreted as semi-elasticities.

Our two main variables of interest are the proxy for distance of the exported product to the comparative advantage of the exporting country $\left(D C A_{c k, t_{z}}\right)$ and the interaction term of this proxy with the strength of the banking sector in the exporting country $\left(B C_{c, t_{z}} * D C A_{c k, t_{z}}\right)$. The param- 
eter $\beta_{1}$ captures the disciplining effect of the competitive US market. In particular, the variable $D C A_{c k, t_{z}}$ captures the strength of competitive pressures that a given product faces in the US destination market dependent on how optimally it uses the available production factors endowment of the exporting country. A positive coefficient $\beta_{1}$ would confirm that products using a high share of scarce rather than abundant production factors of the exporting country indeed face a higher hazard rate in the US market. The parameter $\beta_{2}$ captures the additional role of banks in reinforcing this pattern. A positive coefficient $\beta_{2}$ would suggest that a strong banking system pushes the export composition towards the comparative advantage of a given country even before the competition in the US market sets in. ${ }^{31}$ Positive coefficients $\beta_{1}$ and $\beta_{2}$ would also be in accordance with hypotheses H1 and H2 derived in the context of our simple model in Section 2.

In some regressions, we also use other banking variables that measure various dimensions of the banking system in the country of origin - bank assets, total credit, non-bank credit, and credit to government. Similarly to our main banking proxy, these measures also enter the regressions both directly $\left(B A_{c, t_{z}}, T C_{c, t_{z}}, N B C_{c, t_{z}}, G C_{c, t_{z}}\right)$ and interacted with the distance of the exported product to the comparative advantage of the exporting country $\left(B A_{c, t_{z}} * D C A_{c k, t_{z}}, T C_{c, t_{z}} * D C A_{c k, t_{z}}\right.$, $\left.N B C_{c, t_{z}} * D C A_{c k, t_{z}}, G C_{c, t_{z}} * D C A_{c k, t_{z}}\right)$.

We control for heterogeneity across manufacturing sectors by fitting a stratified Cox model at the industry level $j$. This allows the shape of the baseline hazard function, $h_{0, j}(t)$, to vary across 118 ISIC 4-digit industries and adds more flexibility to the model. We also address the omitted variable bias by the use of fixed effects. In the Cox model, the inclusion of fixed effects results in a shift of the baseline hazard function. The exporting-country fixed effects $\left(\delta_{c}\right)$ control for a wide array of observable and unobservable characteristics of exporting countries that might affect the chances of their products to survive in the US market. These factors include physical and cultural proximity to the USA, common border, common language, etc. The initiation-year fixed effects $\left(\delta_{t_{z}}\right)$ control for the possibility that the initial conditions in the first year of export spell $\left(t_{z}\right)$ might influence the products' chances for subsequent survival in the US market.

The vector $\mathbf{x}$ includes the GDP per capita of the exporting country $c$ taken in $\log$ terms

\footnotetext{
$31 \mathrm{Ai}$ and Norton (2003) discuss the issues associated with estimating a non-linear model with interaction terms. As a robustness check, we define a time-varying dummy variable marking countries with high level of banking development. We set $\lambda_{t_{z}}$ at the 75th percentile of the cross-sectional distribution of countries' level of banking development. We split our measure of distance to comparative advantage in two, one for countries in the bottom 75 th percentile $\left(B_{75} * D C A_{c k, t_{z}}\right)$ and one for countries in the top 25th percentile $\left(T_{25} * D C A_{c k, t_{z}}\right)$ regarding the level of banking development. We then re-run our estimations, replacing the interaction term between the level of banking sector development and the measure of distance to comparative advantage $\left(B C_{c, t_{z}} * D C A_{c k, t_{z}}\right)$ with these two new distance measures $\left(B_{75} * D C A_{c k, t_{z}}, T_{25} * D C A_{c k, t_{z}}\right)$. Results confirm the additional effect of banking development. The coefficients are increasing in magnitude from the bottom 75 th percentile to the top 25th percentile and are statistically significantly different from each other. Results are available upon request.
} 
$\left(G D P p c_{c, t_{z}}\right)$, country c's endowments in physical and human capital $\left(\kappa_{c, t_{z}}, h_{c, t_{z}}\right)$ and their interactions with the corresponding capital intensities at the industry level $\left(\kappa_{c, t_{z}} * \operatorname{CapInt}_{j}, h_{c, t_{z}} *\right.$ HumInt $_{j}$ ), as well as several product-related control variables. We include the log value of export of product $k$ from country $c$ to the US market in the initial year of the trade relationship $t_{z}$ (initial_export $\left.{ }_{c k, t_{z}}\right)$. This reflects the level of confidence importers in the USA have in the reliability of their trading partners. Additionally, we include the total log export value of product $k$ from country $c$ to all countries in the initial year of the trade relationship (total_export ${ }_{c k, t_{z}}$ ). This variable captures the experience the exporting country has in supplying the world market with product $k$. We further control for the varying degree of competition in the US product markets by incorporating the number of countries exporting a given product $k$ to the USA in year $t_{z}$ (NSupplier $s_{k, t_{z}}$ ). We also account for trade relationships that experience multiple spells within the same (exporting country)*product pair by including a dummy variable (multiple_spell ${ }_{c k}$ ) marking all spells within such "on-and-off" trade relationships. ${ }^{32}$ In some specifications, the vector $\mathbf{x}$ also includes GDP per capita of the exporting country $c$ interacted with the distance to comparative advantage $\left(G D P_{c, t_{z}} * D C A_{c k, t_{z}}\right)$, real exchange rate $\left(R E R_{c, t_{z}}\right)$, and real exchange rate interacted with the distance to comparative advantage $\left(R E R_{c, t_{z}} * D C A_{c k, t_{z}}\right)$.

Finally, we re-estimate Equation 11, stratifying by product $k$, allowing the baseline function to vary across individual products rather than just across industries. The estimating equation then becomes:

$h_{c k}(t)=h_{0, k}(t) \exp \left[\beta_{1} D C A_{c k, t_{z}}+\beta_{2} B C_{c, t_{z}} * D C A_{c k, t_{z}}+\gamma B C_{c, t_{z}}+\mathbf{x}_{c k, t_{z}} \phi+\delta_{c}+\delta_{t_{z}}+\varepsilon_{c k, t_{z}}\right]$

This specification allows for a different baseline hazard function, $h_{0, k}(t)$, for every of the 4,562 analyzed products from the HS 6-digit classification. In terms of controlling for product heterogeneity, the specification is thus even more stringent than would be a one including product fixed effects. Fixed effects merely shift the baseline hazard function while stratification allows different products to have different underlying hazard functions (see Online Appendix B for a more technical treatment of this issue). In Online Appendix C.1, we allow the underlying hazard rate to differ even for the same product $k$ if the export spell started in different year $t_{z}$.

\footnotetext{
${ }^{32}$ Online Appendix C.2 reports results for alternative methods of handling multiple spells.
} 


\subsection{The Role of Stock Markets}

As the next step in our analysis, we examine whether well-developed stock markets also enhance the disciplining effect of product markets in the context of international trade. We re-estimate Equation 11, replacing the variable measuring the strength of the banking sector $\left(B C_{c, t_{z}}\right)$ with the ratio of the stock market capitalization over the GDP in the exporting country $c$ measured in the initiation year of the export spell $t_{z}\left(S t M_{c, t_{z}}\right)$. This variable captures the depth and liquidity of stock markets in the exporting country. The estimating equation focusing on the role of stock markets in enhancing the product market discipline thus writes:

$h_{c k}(t)=h_{0, j}(t) \exp \left[\beta_{1} D C A_{c k, t_{z}}+\beta_{2} S t M_{c, t_{z}} * D C A_{c k, t_{z}}+\gamma S t M_{c, t_{z}}+\mathbf{x}_{c k, t_{z}} \phi+\delta_{c}+\delta_{t_{z}}+\varepsilon_{c k, t_{z}}\right](13$

where $\varepsilon_{c k, t_{z}}$ is the error term. As previously, Equation 13 is estimated using partial maximum likelihood and standard errors are clustered at the (exporting country)*(initiation year) level ( $c *$ $\left.t_{z}\right)$. We also include exporting-country and initiation-year fixed effects $\left(\delta_{c}, \delta_{t_{z}}\right)$ and stratify the estimation by 118 ISIC 4 -digit industry categories $j$. The parameter $\beta_{1}$ captures the disciplining effect of the competitive US market and the parameter $\beta_{2}$ captures the additional effect of welldeveloped stock markets in the exporting country.

In some regressions, we use stock market value traded and stock market turnover as alternative measures of the depth and liquidity of stock markets in the exporting country. Like with other

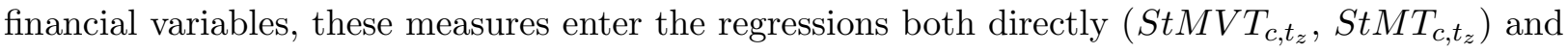
interacted with the distance of the exported product to the comparative advantage of the exporting country $\left(S t M V T_{c, t_{z}} * D C A_{c k, t_{z}}, S t M T_{c, t_{z}} * D C A_{c k, t_{z}}\right)$. The non-financial control variables are identical to the ones in Equation 11.

Similarly to the regressions focusing on the banking sector, also in the case of stock markets we re-estimate Equation 13, stratifying at the product level $k$ and thus allowing the baseline hazard function $h_{0}$ to vary across the 4,562 products according to the HS 6-digit classification:

$h_{c k}(t)=h_{0, k}(t) \exp \left[\beta_{1} D C A_{c k, t_{z}}+\beta_{2} S t M_{c, t_{z}} * D C A_{c k, t_{z}}+\gamma S t M_{c, t_{z}}+\mathbf{x}_{c k, t_{z}} \phi+\delta_{c}+\delta_{t_{z}}+\varepsilon_{c k, t_{z}}\right](14$

\subsection{Estimation Issues}

The previous subsections described our general empirical strategy, including our handling of the omitted variables bias. We discussed the use of control variables, employment of the full sets 
of exporting-country and initiation-year fixed effects, and stratification of the estimated equation at the industry and product level. However, estimating the effect of financial institutions and markets on export survival raises some further identification issues, like endogeneity or unobserved heterogeneity. In this section, we describe these issues and our handling of them.

First, financial development may be endogenous to export performance (Do and Levchenko, 2007). In particular, our regressors measuring the strength of banks and the depth of stock markets in exporting countries could be subject to the endogeneity bias if credit and/or stock markets in the economy expand in anticipation of future export booms. Fortunately, this bias is less of an issue in our survival framework where the dependent variable is the hazard rate of highly disaggregated trade relationships and not the annual volume of export. Additionally, we measure all explanatory variables, including our bank and stock market proxies, in the initiation years of these individual trade relationships $\left(t_{z}\right)$.

Second, there are some issues associated with using the Cox model in the context of export survival. ${ }^{33}$ The Cox model is based on the assumption that the explanatory variables influencing survival have a proportionate impact on the baseline hazard function. A change in covariates would thus shift the hazard function by the same factor in any period. Brenton, Saborowski, and von Uexkull (2010) provide evidence that this restrictive assumption typically does not hold in exportduration samples. The violation of the proportional hazards assumption may be due to unobserved heterogeneity that causes the estimated parameters to depend on the duration time. Alternatively, it may be that the effect of the explanatory variables is intrinsically non-proportional. Our Cox model is stratified to account for unobserved time-invariant heterogeneity at the industry or product level. This implies that the baseline hazard rate varies across industries and products. However, covariate effects are still assumed to be constant across industry or product strata. ${ }^{34}$ In order to account for unobserved heterogeneity and for the possibility of intrinsically non-proportional effects of explanatory variables, we will follow Araujo, Mion, and Ornelas (2014) and estimate a variant of our main specification using a linear probability model with fixed effects in one of the robustness checks reported in Online Appendix C.3.

Finally, because all our financial variables $\left(B C_{c, t_{z}}, S t M_{c, t_{z}}\right.$, etc.) vary at the country-time level, where time $t_{z}$ stands for the year when the export spell has been initiated, we report in all tables robust standard errors clustered at the country*(initiation year) level. This procedure

\footnotetext{
33 See Hess and Persson (2012) for a full discussion of the drawbacks of Cox regressions in the context of trade data and alternative estimators.

${ }^{34}$ Stratification in the continuous Cox model is equivalent to modeling frailty with a gamma distribution in a discrete-time duration model (Hosmer, Lemeshow, and May, 2008).
} 
avoids biasing the standard errors downwards for our financial development variables whose value is constant across product-level observations within the country-time clusters (Moulton, 1986, 1990; Cameron and Trivedi, 2005). We will cluster standard errors also at the country level (Bertrand, Duflo, and Mullainathan, 2004) and use the two-way clustering for standard errors (Cameron, Gelbach, and Miller, 2006) as additional robustness checks in Online Appendix C.1.

\section{Empirical Results}

\subsection{The Role of Banks}

In Table III, we investigate the interplay between disciplinary pressures from product markets and banks towards exporting patterns congruent with the idea of comparative advantage. Table III reports estimates using Equation 11 in columns (1) to (3) and Equation 12 in columns (4) to (6). The dependent variable is the probability of exiting the US market (hazard rate, in the terminology of survival analysis) for product $k$ exported from country $c$. All regressions control for fixed effects at the level of exporting countries and initiation years of the export spells.

Columns (1) to (3) of Table III allow for different baseline hazard rate across industries by defining industry as the strata variable (Equation 11). The first column focuses on the disciplining impact of product markets. The positive and significant coefficient for the distance to comparative advantage $\left(D C A_{c k, t_{z}}\right)$ confirms the importance of competitive product markets in enforcing the optimal allocation of resources. Products with factor intensity far away from the endowment of the exporting country face a significantly higher probability of failure in the US destination market. In terms of control variables, higher initial values of exports both to the US and to all destinations $\left(\right.$ initial_export $_{c k, t_{z}}$, total_export $\left._{c k, t_{z}}\right)$ decrease the hazard rate. Intuitively, products survive longer on the US market when the importers are willing to accept a higher initial shipment and when the exporting country has experience with exporting a given product to other markets as well. The coefficient for the multiple spell dummy (multiplespell $l_{c k}$ ) is positive and significant, suggesting a higher risk of failure for products that repeatedly exit and re-enter the US market. The last product-related variable is the number of suppliers (NSupplier $s_{k, t_{z}}$ ), which has a negative impact on the hazard rate. This result is rather counter-intuitive as a higher number of countries exporting a given product should increase the competition in the destination market. A possible explanation could be the positive network effect among exporters (Koenig, 2009; Cassey and Schmeiser, 2010; Cadot et al., 2013). The effect of the GDP per capita of the exporting country $\left(G D P p c_{c, t_{z}}\right)$ has no significant effect in this specification. 
Table III: Banks and Comparative Advantage

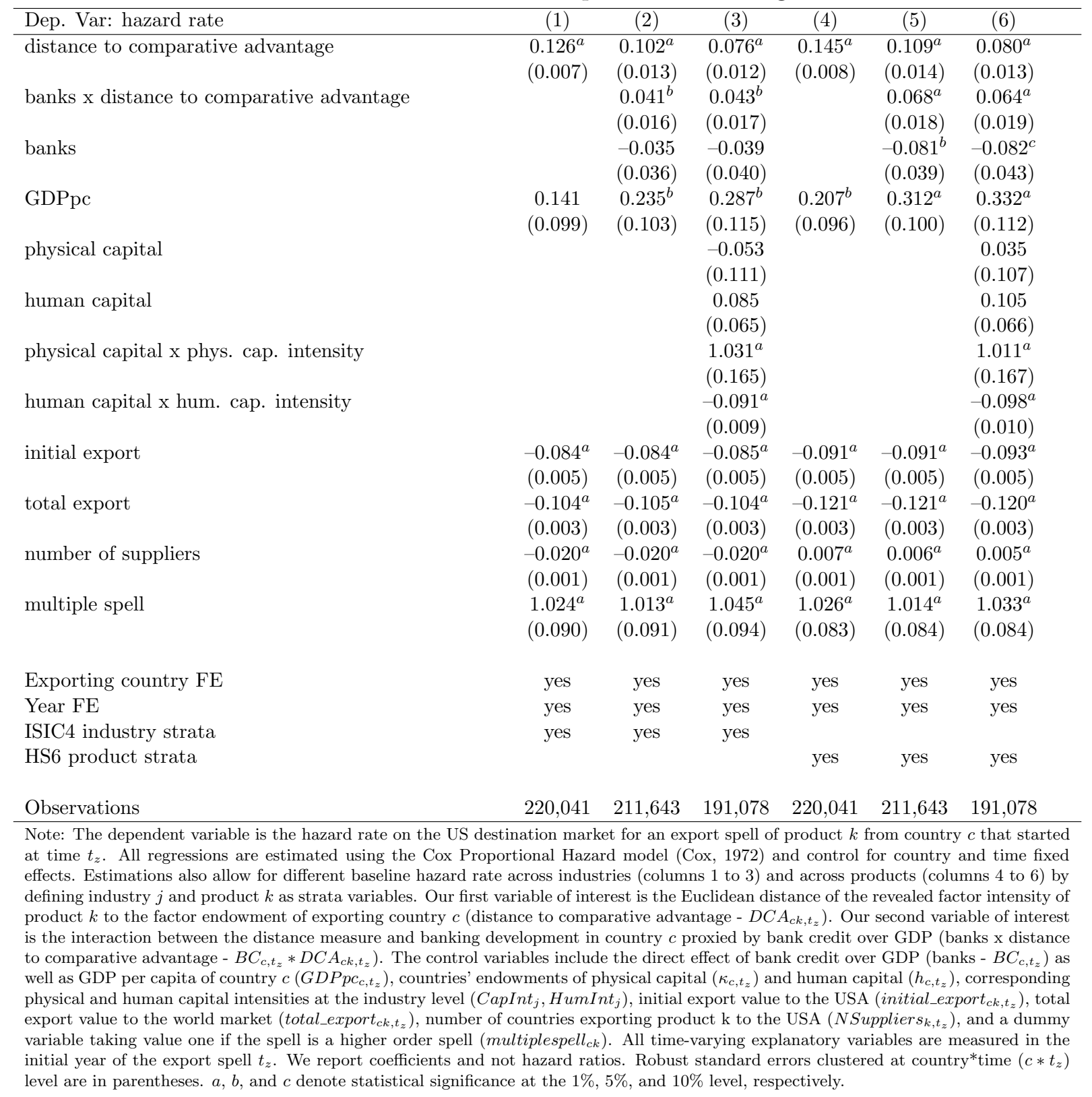

The second column in Table III examines whether domestic banks provide an additional check on inefficient exporting. The regressors now also include the ratio of bank credit over the GDP in the exporting country (banks $-B C_{c, t_{z}}$ ) and an interaction term between this variable and the distance of exported product to the exporting country's comparative advantage (banks x distance to comparative advantage - $B C_{c, t_{z}} * D C A_{c k, t_{z}}$ ). A well-developed banking sector should in general help the exporters survive on foreign markets. Domestic banks $\left(B C_{c, t_{z}}\right)$ indeed lower the hazard rate, but this direct effect is not statistically significant. By contrast, the interaction term between banks and distance to comparative advantage $\left(B C_{c, t_{z}} * D C A_{c k, t_{z}}\right)$ has a positive and statistically significant effect on the hazard rate. The coefficient for the distance to comparative advantage measure $\left(D C A_{c k, t_{z}}\right)$ also remains highly significant. Joint interpretation of positive estimates for 
both coefficients $\left(D C A_{c k, t_{z}}, B C_{c, t_{z}} * D C A_{c k, t_{z}}\right)$ suggests that banks push exporters to abandon products that are already facing an uphill battle on the US destination market due to the suboptimal use of the domestic factor endowments. With regard to our control variables, the GDP per capita of the exporting country $\left(G D P p c_{c, t_{z}}\right)$ has a positive and significant effect on the hazard rate. While this result might appear counter-intuitive at first sight, two features of our estimation strategy provide an explanation. First, we control for exporting-country fixed effects in all regressions. The effect of $G D P p c_{c, t_{z}}$ is thus identified solely from variations within countries over time. These variations emerge both from growth trend and from business cycle fluctuations. Second, we measure all time-varying regressors in the first year of an export spell $\left(t_{z}\right)$. Economically, the positive estimated coefficient for $G D P p c_{c, t_{z}}$ would then imply that exports initiated at the peak of a business cycle in the country of origin face higher risk of failure. Possible reasons for this effect include over-confidence of exporters during a boom or difficulties to maintain the costly presence in the US destination market once the business climate at home deteriorates.

In the third column of Table III, we add interaction terms between the exporting countries' factor endowments and the corresponding factor intensities at the sectoral level (physical capital $\mathrm{x}$ physical capital intensity $-\kappa_{c, t_{z}} *$ CapInt ${ }_{j}$, human capital $\mathrm{x}$ human capital intensity $-h_{c, t_{z}} *$ HumInt $_{j}$ ). These interacted variables control for the possibility that products from industries extensively using physical or human capital survive longer in the US destination market if the exporting country is abundant in such a capital. When adding these interaction terms, we also control for the direct effect of exporting countries' endowments in physical capital $\left(\kappa_{c, t_{z}}\right)$ and human capital $\left(h_{c, t_{z}}\right)^{35}$ while the direct effect of the corresponding factor intensities $\left(\right.$ CapInt $_{j}$, HumInt $_{j}$ ) is captured by the industry strata effects. ${ }^{36}$ Our main interaction term capturing the disciplining effects of banks (banks x distance to comparative advantage - $B C_{c, t_{z}} * D C A_{c k, t_{z}}$ ) maintains a positive and statistically significant coefficient. Similarly, the direct effect of distance to comparative advantage $\left(D C A_{c k, t_{z}}\right)$ still translates into a higher hazard rate of exports, confirming the disciplining impact of the competitive US market. The interaction term between human capital and human capital intensity $\left(h_{c, t_{z}} * H u m I n t_{j}\right)$ has the expected negative sign while the direct effects of endowments in physical and human capital $\left(\kappa_{c, t_{z}}, h_{c, t_{z}}\right)$ are insignificant. The interaction between

\footnotetext{
35 Countries' factor endowments are time-varying variables measured in the initial year of a trade relationship. Direct impact of the physical and human capital $\left(\kappa_{c, t_{z}}, h_{c, t_{z}}\right)$ is therefore not absorbed by the exporting country fixed effects. The same logic also applies to other time-varying characteristics of the exporting countries like the bank credit over GDP $\left(B C_{c, t_{z}}\right)$ or the GDP per capita $\left(G D P p c_{c, t_{z}}\right)$.

36 To be precise, this capturing is not complete due to application of concordances in order to match data measured in different classifications as described in the data section. We do not report the coefficients for direct effect of factor intensities as these do not have a meaningful economic interpretation and are a mere artefact of the circumstance that official concordances sometimes match an ISIC 3-digit industry according to Revision 2 to more than one ISIC 4-digit industry according to Revision 3.
} 
physical capital and physical capital intensity $\left(\kappa_{c, t_{z}} *\right.$ CapInt $\left.t_{j}\right)$ has a positive sign, suggesting that products of capital-intensive industries coming from capital-abundant countries face a higher risk of exit from the US destination market. This rather counter-intuitive result is similar to Manova (2008), who finds a negative effect of this interaction term on export volume.

In columns (4) to (6) of Table III, we explore the disciplining effects of the US destination market and banking system in the country of origin within a more stringent econometric specification. We replicate the specifications in columns (1) to (3) but apply the stratification according to HS 6-digit products (Equation 12) rather than ISIC 4-digit industries. Concerning our main focus on the interplay between disciplining forces of product markets and banks, the results confirm in qualitative terms those obtained in columns (1) to (3). Both distance to the comparative advantage and the interaction of this variable with the strength of banking system in the country of origin retain a positive and significant effect on products' probability of exit from the US market. Furthermore, both the point estimate and the significance level of our main interaction term (banks $\mathrm{x}$ distance to comparative advantage - $\left.B C_{c, t_{z}} * D C A_{c k, t_{z}}\right)$ increase after stratification at the product rather than just industry level. Accounting for unobserved heterogeneity at the product level also yields two changes regarding our control variables. First, the number of suppliers (NSupplier $s_{k, t_{z}}$ ) - measuring the number of countries exporting the given product to the US and thus capturing the strength of import competition on the US product markets - now has the expected positive sign, increasing the products' hazard rate. Second, the expected negative direct effect of banks $\left(B C_{c, t_{z}}\right)$ on the hazard rate is now statistically significant in the fifth and sixth column where it is included.

Column (6) of Table III represents our preferred specification. Unless stated otherwise, later estimations take this specification as the reference point. Overall, the results from Table III suggest a statistically significant disciplining effect of both product markets and banks when it comes to terminating exports to the US that do not optimally use the available factors of production in the countries of origin. Before moving to further empirical analysis, let us consider the economic significance of our results.

One way to get a sense of the economic magnitude regarding our results is as follows. Let us assume that Turkey would reach the average level of banking development among the OECD countries, i.e. the value of the variable $B C_{c, t_{z}}$ would increase from 0.16 to 0.84 . Equation 12 and estimated coefficients from column (6) of Table III then imply that the hazard rate for any given product exported from Turkey to the USA would change by $\beta_{2} \Delta B C_{c, t_{z}} * D C A_{c k, t_{z}}+\gamma \Delta B C_{c, t_{z}}=$ $\Delta B C_{c, t_{z}} *\left[\beta_{2} D C A_{c k, t_{z}}+\gamma\right]=(0.84-0.16) *\left[0.064 * D C A_{c k, t_{z}}-0.082\right]$. In case of a product that is 
far away from the comparative advantage of Turkey like "Equipment for automatically developing photographic films" ( $D C A_{c k, t_{z}}=1.90$, in the top 25th percentile), the hazard rate of exports would then increase by approximately 2.7 per cent: $(0.84-0.16) *[0.064 * 1.90-0.082]=0.027$. In case of a product well aligned with with Turkish comparative advantage like "Footwear with leather" $\left(D C A_{c k, t z}=0.71\right.$, in the bottom 25 th percentile), the hazard rate would actually decrease by approximately 2.5 per cent: $(0.84-0.16) *[0.064 * 0.71-0.082]=-0.025$. In case of Turkey, a better developed banking sector could thus increase the difference in export hazard rates between products in the top and bottom 25 th percentile of distance to comparative advantage by 5.2 per cent. This is a large effect, also when compared to the direct disciplining impact of product markets. Taking the example of the same two Turkish exports but abstracting from the impact of banks and considering only the effect of distance to comparative advantage would namely suggest that the product "Equipment for automatically developing photographic films" faces approximately a 17 per cent higher hazard rate on the US destination market than the product "Footwear with leather". 37,38

In Table IV, we further examine the disciplining role banks have on exports not corresponding to the notion of comparative advantage. In columns (1) to (2), we look at alternative proxies of the strength of the banking sector in the exporting country. In columns (3) to (6), the focus is on the disciplining role of traditional banks versus the impact of various other financial institutions.

Column (1) of Table IV reports the results of our preferred specification from column (6) in Table III, replacing the credit by banks to private real sector $\left(B C_{c, t_{z}}\right)$ with the overall bank assets $\left(B A_{c, t_{z}}\right)$ - both normalized by GDP of a given country. The main interaction term in the first column of Table IV is thus bank assets $\mathrm{x}$ distance to comparative advantage $\left(B A_{c, t_{z}} * D C A_{c k, t_{z}}\right)$. In column (2), we replace the bank credit $\left(B C_{c, t_{z}}\right)$ with the total credit by both banks and other financial institutions $\left(T C_{c, t_{z}}\right)$ - again, normalized by GDP. The main interaction term thus becomes total credit $\mathrm{x}$ distance to comparative advantage $\left(T C_{c, t_{z}} * D C A_{c k, t_{z}}\right)$. Compared to Table III, column (1) of Table IV looks at a broader measure of the claims banks have on the rest of the economy rather than at extended credit alone while column (2) looks at credit extended by a broader set of financial institutions rather than by the deposit-taking money banks alone. Our main results from Table III are robust to using these broader measures of the importance of

\footnotetext{
37 The estimated coefficient for $D C A_{c k, t_{z}}$ in column (4) of Table III that abstracts from the impact of banks is 0.145 , implying a following computation: $0.145 *(1.90-0.71) \simeq 0.173$.

38 To put our result in the broader context of existing research on financial development and the real economy, let us mention the economic magnitude found in one of the seminal papers in this area. Rajan and Zingales (1998, p. 574) show that an industry at the 75 th percentile of financial dependence would grow 1.3 per cent faster than an industry at the 25th percentile of financial dependence if it were located in Italy as opposed to less financially developed Philippines. The 1.3 per cent should in this case be compared to an average growth rate of 3.4 per cent.
} 
Table IV: Alternative Measures of Banks and Comparative Advantage

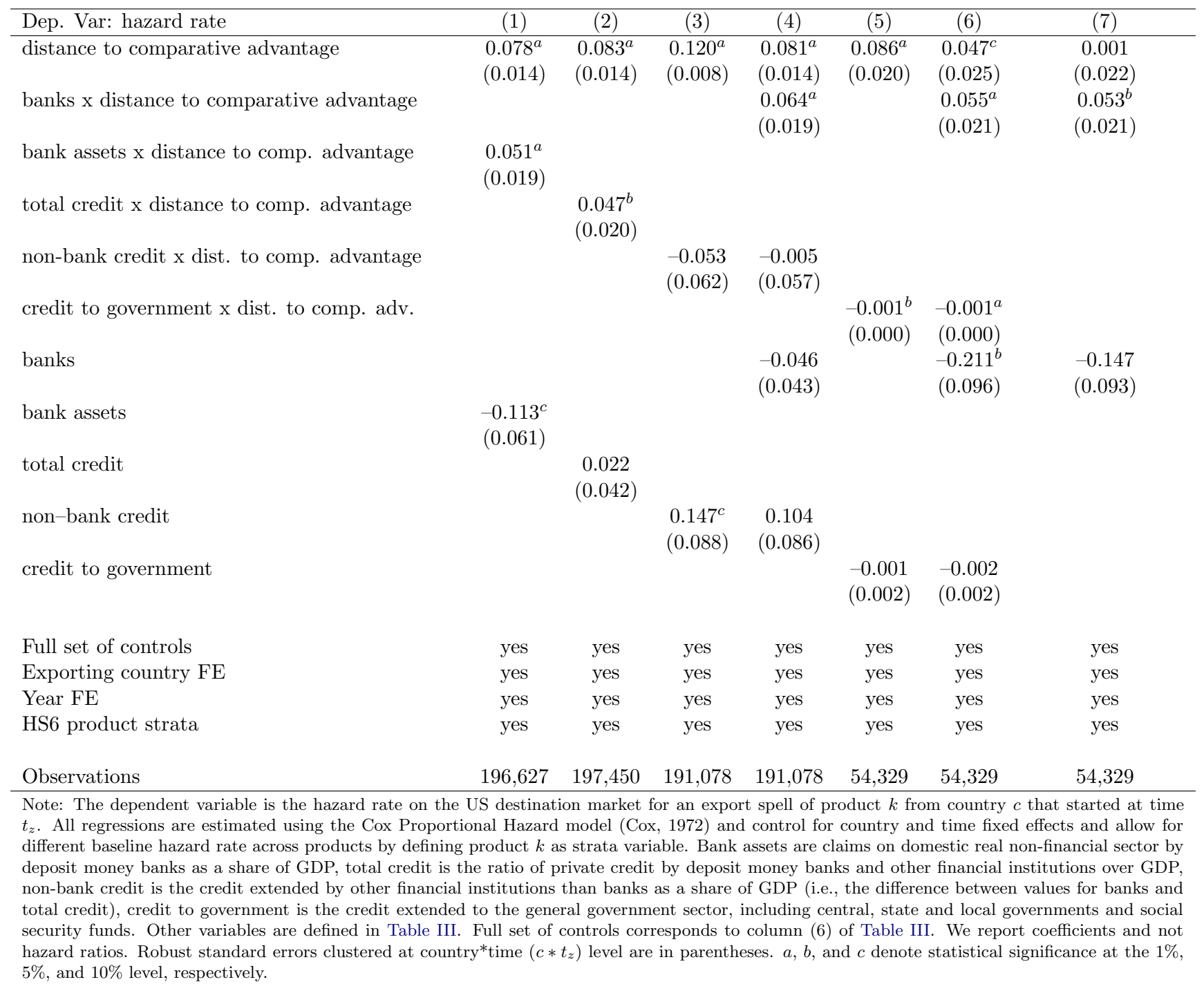

financial institutions for the real economy.

Comparing column (2) from Table IV to column (6) from Table III, it seems that the results for a broader set of financial institutions is somewhat weaker than when looking at traditional banks alone. In particular, the main interaction term in column (2) of Table IV (total credit $\mathrm{x}$ distance to comparative advantage - $\left.T C_{c, t_{z}} * D C A_{c k, t_{z}}\right)$ has a lower level of significance, suggesting a possibly lower disciplining effect of other financial institutions on exporting activities of the real sector. This could be explained by the presence of state banks and other governmental financial institutions in many countries in our sample. These institution do not rely on deposit taking but receive a bulk of their funding directly from government. Arguably, such institutions face lower pressure to invest their funds efficiently and are thus less suitable as a disciplining device towards their own borrowers. We examine this hypothesis more directly in column (3) of Table IV, where our main financial proxy is the difference between total credit by all banks and financial institutions 
and the credit extended by deposit-taking money banks, capturing the credit extended by other financial institutions (non-bank credit $-N B C_{c, t_{z}}$ ). The non-significant interaction term between non-bank credit and distance to comparative advantage $\left(N B C_{c, t_{z}} * D C A_{c k, t_{z}}\right)$ confirms that when it comes to inefficient exporting, other financial institutions lack the disciplining impact of deposittaking banks. This picture is further reinforced in column (4) where the two proxies capturing the strength of banks and the strength of other financial institutions jointly enter the regression. While the interaction term between banks and distance to comparative advantage has the expected sign and a high level of statistical significance, the interaction of non-bank credit and distance to comparative advantage remains insignificant.

In columns (5) and (6) of Table IV, we distinguish between credit extended to private nonfinancial sector and credit extended to government. If our results are driven by the specific disciplining role of banks towards firms rather than by some general pattern of exporting during credit booms, credit to government $\left(G C_{c, t_{z}}\right)$ should not have the same impact on terminating inefficient exports. And indeed, high levels of credit extended to government of the exporting country has actually a worsening impact on resource allocation, by disproportionately lowering the hazard rate of exports not corresponding to comparative advantage of exporting country. In particular, the interaction term between credit to government and distance to comparative advantage $\left(G C_{c, t_{z}} * D C A_{c k, t_{z}}\right)$ is negative and significant in column (5) of Table IV. This result for credit to government remains the same in column (6) where we allow our main interaction of banks and distance to comparative advantage to enter the regression. In contrast, the main interaction term itself is significant and of expected sign in column (6).

The last column of Table IV performs an additional robustness test due to the significantly lower number of observations in columns (5) and (6). Data on government credit are available only for a smaller subset of countries, so that the results in column (6) could be partially driven by multicollinearity between the bank credit to private non-financial sector and the credit to government in the small sample. In column (7) of Table IV, we thus re-run the estimation on the smaller sample from previous two columns but allow only the interaction of banks and distance to comparative advantage to enter the regression. Even without the presence of government credit in the estimation, the disciplining impact of banks on export does survive, as can be seen from the positive and significant impact of the main interaction term (banks $\mathrm{x}$ distance to comparative advantage $\left.-B C_{c, t_{z}} * D C A_{c k, t_{z}}\right)$ on the hazard rate of exports into USA.

Overall, results in Table IV provide further evidence that a strong banking sector in the ex- 
porting country can enhance the disciplining impact of the US destination market when it comes to products not corresponding to the comparative advantage of the country exporting to the USA. While it does not matter whether the importance of banking sector in the economy is measured by credit extended to private non-financial sector or by the overall bank assets, other financial institutions do not seem to exert the same disciplining effect as banks. And the credit extended to government has, if anything, a negative impact on the resource allocation. These results are in line with conventional wisdom both about monitoring abilities of banks and about potential misallocative effects related to financial flows where either the lender or borrower has access to taxpayers' money. We plan to look deeper into this issue in our future work.

\section{Banks and Bond Markets}

When it comes to the disciplining role of external debt, existing literature often does not distinguish between private creditors (e.g., banks extending credit to firms) and public creditors (e.g., holders of publicly tradable corporate bonds). However, Denis and Mihov (2003) extend the arguments by Stulz (1990) and Berger, Ofek, and Yermack (1997) about the role of managerial discretion in choosing the debt/equity ratio to the case of public versus private debt and argue that private lenders like banks are better equipped to push firms' management towards optimal level of investment than public debtholders are. This is due to their concentrated holdings of external debt and superior access to information. Lin et al. (2013) make a similar argument regarding the monitoring abilities of banks versus the holders of public debt. ${ }^{39}$

For completeness, Table XIII in the Appendix A reports additional regressions that include three proxies for the strength of bond markets in countries exporting to the USA: domestic private bonds (columns 2-3), international private bonds (columns 5-6) and international bonds issued by non-financial firms only (columns 8-9) - all normalized by the GDP of the exporting country. Given the somewhat limited availability of internationally comparable data on bond markets, the number of observations is lower for all three bond markets proxies compared to our main bank proxy. For better comparison, columns (1), (4), and (7) of Table XIII therefore report results in these reduced samples for the specification from column (6) of Table III that focuses on our main banking channel. Columns (2), (5), and (8) report the regression results with the interactions of our three bond markets proxies with distance to comparative advantage measure. Finally, columns (3), (6), and (9) allow for the possibility that both strong banks and well-developed bond markets

\footnotetext{
${ }^{39}$ Recent papers that examine bank loans versus public bonds from different perspectives than disciplining role of debt include Gomes and Phillips (2012), Colla, Ippolito, and Li (2013), and Morellec, Valta, and Zhdanov (2015).
} 
in exporting countries increase the hazard rate in the US destination market disproportionately for those products that do not correspond to the comparative advantage of the exporting country.

In Table XIII, the bank interaction term is always positive and significant when included, confirming the importance of the banking sector in the exporting country when it comes to enhancing the disciplining impact of the US destination market on products far away from the comparative advantage of the exporting country. When it comes to the bond markets, only the interaction term of the first bond proxy with distance to comparative advantage enters significantly the regressions in columns (2) and (3). This results may be explained by the fact that both this proxy and the proxy entering columns (5) and (6) of Table XIII include bonds issued by financial firms like banks themselves. These bonds can arguably contribute to financing bank operations that support exporting activities of firms and do not necessarily show up in data on bank loans (e.g., letters of credit, export insurance). In future research, we plan to look further into disentangling these channels. Importantly for the purposes of this paper, the interaction term of distance to comparative advantage with the one bond proxy that does capture solely the bonds issued by non-financial firms is not significant in columns (8) and (9) of Table XIII. Overall, these results suggest that private debtholders like banks are indeed more effective than bondholders when it comes to disciplining firms' export behavior.

\subsection{The Role of Stock Markets}

In Table V, we repeat the estimations from Table III, but in the main interaction term we replace the ratio of private credit over GDP with the ratio of stockmarket capitalization over GDP. Specifications in columns (1) to (3) allow for a different baseline hazard rate across 118 ISIC 4-digit industries (Equation 13) while the regressions reported in columns (4) to (6) allow the baseline hazard rate to vary across all 4,562 HS 6-digit products (Equation 14). A positive coefficient for the resulting variable (stock markets $\mathrm{x}$ distance to comparative advantage $-S t M_{c, t_{z}} * D C A_{c k, t_{z}}$ ) would suggest that shareholders are also able to exert a disciplining influence on exports that do not correspond to the exporting country's comparative advantage. The results in Table V do not support this hypothesis. The interaction term between stock market capitalization and distance to comparative advantage is never significant and once even enters the regression with the wrong sign.

Table VI further explores whether stock markets in exporting countries play a role in enhancing the disciplining effects of the US product market. Columns (1) and (2) report the results of 
Table V: Stock Markets and Comparative Advantage

\begin{tabular}{|c|c|c|c|c|c|c|}
\hline Dep. Var: hazard rate & (1) & (2) & $(3)$ & $(4)$ & $(5)$ & $(6)$ \\
\hline \multirow{2}{*}{ distance to comparative advantage } & $0.126^{a}$ & $0.131^{a}$ & $0.098^{a}$ & $0.145^{a}$ & $0.147^{a}$ & $0.108^{a}$ \\
\hline & $(0.007)$ & $(0.011)$ & $(0.010)$ & $(0.008)$ & $(0.012)$ & $(0.011)$ \\
\hline \multirow[t]{2}{*}{ stock markets $\mathrm{x}$ distance to comp. advantage } & & -0.000 & 0.004 & & 0.005 & 0.006 \\
\hline & & $(0.012)$ & $(0.012)$ & & $(0.014)$ & $(0.013)$ \\
\hline \multirow[t]{2}{*}{ stock markets } & & 0.031 & 0.025 & & 0.026 & 0.024 \\
\hline & & $(0.026)$ & $(0.028)$ & & $(0.028)$ & $(0.030)$ \\
\hline \multirow[t]{2}{*}{ GDPpc } & 0.141 & 0.111 & 0.210 & $0.207^{b}$ & $0.193^{c}$ & $0.271^{b}$ \\
\hline & $(0.099)$ & $(0.115)$ & $(0.132)$ & $(0.096)$ & $(0.112)$ & $(0.132)$ \\
\hline \multirow[t]{2}{*}{ physical capital } & & & -0.110 & & & -0.051 \\
\hline & & & $(0.121)$ & & & $(0.119)$ \\
\hline \multirow[t]{2}{*}{ human capital } & & & 0.057 & & & 0.076 \\
\hline & & & $(0.065)$ & & & $(0.066)$ \\
\hline \multirow[t]{2}{*}{ physical capital x phys. cap. intensity } & & & $0.847^{a}$ & & & $0.851^{a}$ \\
\hline & & & $(0.196)$ & & & $(0.195)$ \\
\hline \multirow[t]{2}{*}{ human capital $\mathrm{x}$ hum. cap. intensity } & & & $-0.110^{a}$ & & & $-0.118^{a}$ \\
\hline & & & $(0.010)$ & & & $(0.011)$ \\
\hline \multirow[t]{2}{*}{ initial export } & $-0.084^{a}$ & $-0.085^{a}$ & $-0.087^{a}$ & $-0.091^{a}$ & $-0.093^{a}$ & $-0.096^{a}$ \\
\hline & $(0.005)$ & $(0.005)$ & $(0.005)$ & $(0.005)$ & $(0.005)$ & $(0.005)$ \\
\hline \multirow[t]{2}{*}{ total export } & $-0.104^{a}$ & $-0.105^{a}$ & $-0.103^{a}$ & $-0.121^{a}$ & $-0.126^{a}$ & $-0.124^{a}$ \\
\hline & $(0.003)$ & $(0.003)$ & $(0.003)$ & $(0.003)$ & $(0.003)$ & $(0.004)$ \\
\hline \multirow[t]{2}{*}{ number of suppliers } & $-0.020^{a}$ & $-0.021^{a}$ & $-0.021^{a}$ & $0.007^{a}$ & $0.008^{a}$ & $0.006^{a}$ \\
\hline & $(0.001)$ & $(0.001)$ & $(0.001)$ & $(0.001)$ & $(0.001)$ & $(0.001)$ \\
\hline \multirow[t]{2}{*}{ multiple spell } & $1.024^{a}$ & $1.076^{a}$ & $1.116^{a}$ & $1.026^{a}$ & $1.076^{a}$ & $1.101^{a}$ \\
\hline & $(0.090)$ & $(0.099)$ & $(0.104)$ & $(0.083)$ & $(0.091)$ & $(0.092)$ \\
\hline Exporting country FE & yes & yes & yes & yes & yes & yes \\
\hline Year FE & yes & yes & yes & yes & yes & yes \\
\hline ISIC4 industry strata & yes & yes & yes & & & \\
\hline HS6 product strata & & & & yes & yes & yes \\
\hline Observations & 220,041 & 203,649 & 182,592 & 220,041 & 203,649 & 182,592 \\
\hline \multicolumn{7}{|c|}{$\begin{array}{l}\text { Note: The dependent variable is the hazard rate on the US destination market for an export spell of product } k \text { from country } c \text { that started } \\
\text { at time } t_{z} \text {. All regressions are estimated using the Cox Proportional Hazard model (Cox, 1972) and control for country and time fixed } \\
\text { effects. Estimations also allow for different baseline hazard rate across industries (columns } 1 \text { to } 3 \text { ) and across products (columns } 4 \text { to } 6) \text { by } \\
\text { defining industry } j \text { and product } k \text { as strata variables. Stock markets development of country } c \text { is represented by the ratio of stock market } \\
\text { capitalization over GDP (stock markets - St } M_{c, t z} \text { ). Other variables are defined in Table III. We report coefficients and not hazard ratios } \\
\text { Robust standard errors clustered at country*time }\left(c * t_{z}\right) \text { level are in parentheses. a, b, and } c \text { denote statistical significance at the } 1 \%, 5 \% \\
\text { and } 10 \% \text { level, respectively. }\end{array}$} \\
\hline
\end{tabular}

estimations analogous to column (6) of Table $\mathrm{V}$ with alternative measures of the strength of stock markets in the exporting country. These measures are the value of stock market transactions relative to GDP - stock market value traded $\left(S t M V T_{c, t_{z}}\right)$ and the ratio of the value of total shares traded to market capitalization - stock market turnover $\left(S t M T_{c, t_{z}}\right)$. Both alternative measures are supposed to capture not only size but also liquidity of the stock markets in a given country (for a more detailed discussion of various stock market measures see, e.g., Strieborny and Kukenova, 2016). Like with all other financial proxies, the two alternative measures capturing the depth of stock markets in a given country exporting to the USA enter the regression both directly and interacted with the country-product measure of distance to comparative advantage. In column (1) of Table VI, the interaction of stock market value traded and distance to comparative advantage is insignificant, confirming the results using stock market capitalization in Table V - deep stock markets do not seem to complement the disciplining effect of the US product market that is 
Table VI: Alternative Measures of Stock Markets and Comparative Advantage

\begin{tabular}{|c|c|c|c|c|c|}
\hline Dep. Var: hazard rate & $(1)$ & $(2)$ & $(3)$ & $(4)$ & $(5)$ \\
\hline distance to comparative advantage & $\begin{array}{c}0.117^{a} \\
(0.010)\end{array}$ & $\begin{array}{c}0.124^{a} \\
(0.010)\end{array}$ & $\begin{array}{c}0.086^{a} \\
(0.015)\end{array}$ & $\begin{array}{c}0.089^{a} \\
(0.015)\end{array}$ & $\begin{array}{l}0.094^{a} \\
(0.016)\end{array}$ \\
\hline banks $\mathrm{x}$ dist. to comp. advantage & & & $\begin{array}{c}0.064^{a} \\
(0.023)\end{array}$ & $\begin{array}{l}0.071^{a} \\
(0.022)\end{array}$ & $\begin{array}{l}0.054^{a} \\
(0.020)\end{array}$ \\
\hline stock markets $\mathrm{x}$ dist. to comp. advantage & & & $\begin{array}{l}-0.017 \\
(0.015)\end{array}$ & & \\
\hline stock market value traded $\mathrm{x}$ dist. to comp. advantage & $\begin{array}{l}-0.017 \\
(0.014)\end{array}$ & & & $\begin{array}{r}-0.047^{a} \\
(0.017)\end{array}$ & \\
\hline stock market turnover $\mathrm{x}$ dist. to comp. advantage & & $\begin{array}{r}-0.018^{c} \\
(0.009)\end{array}$ & & & $\begin{array}{l}-0.015 \\
(0.009)\end{array}$ \\
\hline banks & & & $\begin{array}{l}-0.060 \\
(0.044)\end{array}$ & $\begin{array}{l}-0.071 \\
(0.044)\end{array}$ & $\begin{array}{l}-0.050 \\
(0.042)\end{array}$ \\
\hline stock markets & & & $\begin{array}{c}0.053^{c} \\
(0.030)\end{array}$ & & \\
\hline stock market value traded & $\begin{array}{c}0.101^{a} \\
(0.028)\end{array}$ & & & $\begin{array}{c}0.132^{a} \\
(0.030)\end{array}$ & \\
\hline stock market turnover & & $\begin{array}{c}0.037^{c} \\
(0.021)\end{array}$ & & & $\begin{array}{c}0.020 \\
(0.021)\end{array}$ \\
\hline Full set of controls & yes & yes & yes & yes & yes \\
\hline Exporting country FE & yes & yes & yes & yes & yes \\
\hline Year FE & yes & yes & yes & yes & yes \\
\hline HS6 product strata & yes & yes & yes & yes & yes \\
\hline Observations & 180,479 & 179,311 & 175,481 & 173,368 & 172,200 \\
\hline $\begin{array}{l}\text { Note: The dependent variable is the hazard rate on the US dest } \\
\text { at time } t_{z} \text {. All regressions are estimated using the Cox Propo } \\
\text { effects and allow for different baseline hazard rate across produ } \\
\text { stock market capitalization over GDP, stock market value traded } \\
\text { turnover is the ratio of the value of total shares traded to market } \\
\text { corresponds to column }(6) \text { of Table III. We report coefficients } \\
\left(c * t_{z}\right) \text { level are in parentheses. } a, b \text {, and } c \text { denote statistical sig }\end{array}$ & $\begin{array}{l}\text { ket for an } \\
\text { ard model } \\
\text { ing produ } \\
\text { of stock r } \\
\text { ion. Other } \\
\text { zard ratio } \\
\text { the } 1 \%, 5\end{array}$ & $\begin{array}{l}\text { kport spel } \\
\text { Cox, } 197 \\
k \text { as stra } \\
\text { rket tran } \\
\text { ariables a } \\
\text { Robust } \\
\text { and } 10^{\circ}\end{array}$ & $\begin{array}{l}\text { f product } \\
\text { and cont } \\
\text { variable. } \\
\text { ctions rel } \\
\text { defined i } \\
\text { ndard er } \\
\text { evel, resp }\end{array}$ & $\begin{array}{l}\text { from cour } \\
\text { for count } \\
\text { tock mark } \\
\text { ve to GDP } \\
\text { Table III. I } \\
\text { s clusterec } \\
\text { tively. }\end{array}$ & $\begin{array}{l}c \text { that starte } \\
\text { nd time fixe } \\
\text { s the ratio o } \\
\text { stock marke } \\
\text { set of control } \\
\text { country*tim }\end{array}$ \\
\hline
\end{tabular}

captured by the positive and significant direct impact of distance to comparative advantage. In column (2), the interaction of stock market turnover and distance to comparative advantage is marginally significant but with the wrong sign.

Columns (3) to (5) of Table VI report the results of direct horse-races between the effect of banks (measured by our main bank proxy $B C_{c, t_{z}}$ ) and the effect of stock markets (measured by the three alternative stock market proxies - StM $\left.M_{c, t_{z}}, S t M V T_{c, t_{z}}, S t M T_{c, t_{z}}\right)$. In the third column of Table VI, we run an econometric horse-race between our main bank and stock market proxies and include the levels of banking and stock market development (banks - $B C_{c, t_{z}}$, stock markets $\left.-S t M_{c, t_{z}}\right)$ and their interaction with distance to comparative advantage $\left(B C_{c, t_{z}} * D C A_{c k, t_{z}}\right.$, $\left.S t M_{c, t_{z}} * D C A_{c k, t_{z}}\right)$ simultaneously into our specification. The coefficients for distance to comparative advantage $\left(D C A_{c k, t_{z}}\right)$ and its interaction with banks $\left(B C_{c, t_{z}} * D C A_{c k, t_{z}}\right)$ are both positive and highly significant. In contrast, the interaction term between stock markets and distance to comparative advantage $\left(S t M_{c, t_{z}} * D C A_{c k, t_{z}}\right)$ is non-significant in this specification, further confirming the results from Table V. In columns (4) and (5) of Table VI, the econometric horse-race is between our main bank proxy and the alternative stock market measures from the first two 
columns of Table VI. The previously insignificant interaction term of stock market value traded from column (1) becomes significant but with wrong sign in column (4) while the previously significant interaction of stock market turnover from column (2) gets insignificant when controlling for the bank channel in column (5). In contrast, the coefficients for distance to comparative advantage and its interaction term with banks have once again the right sign and are highly significant in both column (4) and (5) of Table VI.

Overall, the results in Table V and Table VI suggest that stock markets do not exercise the same disciplining impact on the exports as banks and therefore do not complement the positive allocative impact of the competitive US markets in this regard, in accordance with the conjecture discussed at the end of Section 2. The occasional significance of the wrong sign for the interactions of distance to comparative advantage with some stock markets proxies in some specifications is somewhat puzzling and warrants further research. We will provide some preliminary evidence for a possible explanation in the next subsection where we look at alternative channels that could be correlated with the disciplining impact of product markets in the destination country and banks and stock markets in the country of origin.

\subsection{Alternative Channels}

One concern in estimations reported in the previous two subsections is that the bank and stock market interaction terms may be picking up effects of other alternative channels that could be correlated with our mechanism. In Table VII, we therefore re-estimate our baseline specification that entails the bank interaction term (column 6 in Table III), while adding the interaction term of our main stock market variable with distance to comparative advantage as well as additional controls capturing possible alternative channels. In Table VIII and Table XIV in Appendix A, we further examine the interplay between our channel and the traditional channel from finance-trade literature that focuses on financial development alleviating financial frictions.

In the first column of Table VII, we control for an alternative channel from finance to export survival. The seminal paper of Rajan and Zingales (1998) emphasizes the beneficial impact of a well-developed financial system for financially constrained industries that are highly dependent on external financing. Jaud, Kukenova, and Strieborny (2009) confirm the relevance of this mechanism in the context of export survival. They show that a strong financial sector facilitates export survival disproportionately for those sectors that do not generate enough cash-flow to cover their investment needs and therefore have to rely on external finance. In the first column, we therefore augment 
Table VII: Banks, Stock Markets, and Comparative Advantage: Alternative Channels

\begin{tabular}{|c|c|c|c|c|}
\hline Dep. Var: hazard rate & (1) & $(2)$ & $(3)$ & $(4)$ \\
\hline distance to comparative advantage & $\begin{array}{l}0.090^{a} \\
(0.014)\end{array}$ & $\begin{array}{c}0.163^{c} \\
(0.090)\end{array}$ & $\begin{array}{l}2.630^{a} \\
(0.812)\end{array}$ & $\begin{array}{c}2.650^{a} \\
(0.858)\end{array}$ \\
\hline banks $\mathrm{x}$ dist. to comp. advantage & $\begin{array}{l}0.051^{b} \\
(0.022)\end{array}$ & $\begin{array}{c}0.070^{a} \\
(0.025)\end{array}$ & $\begin{array}{c}0.042^{c} \\
(0.024)\end{array}$ & $\begin{array}{c}0.045^{c} \\
(0.026)\end{array}$ \\
\hline stock markets $\mathrm{x}$ dist. to comp. advantage & $\begin{array}{l}-0.016 \\
(0.015)\end{array}$ & $\begin{array}{l}-0.016 \\
(0.015)\end{array}$ & $\begin{array}{c}-0.037^{b} \\
(0.015)\end{array}$ & $\begin{array}{c}-0.033^{b} \\
(0.015)\end{array}$ \\
\hline banks $\mathrm{x}$ dep. on ext. finance & $\begin{array}{c}-0.222^{a} \\
(0.037)\end{array}$ & & & $\begin{array}{c}-0.245^{a} \\
(0.040)\end{array}$ \\
\hline GDPpc $\mathrm{x}$ dist. to comp. advantage & & $\begin{array}{l}-0.009 \\
(0.011)\end{array}$ & & $\begin{array}{c}-0.037^{a} \\
(0.012)\end{array}$ \\
\hline real exchange rate $\mathrm{x}$ dist. to comp. advantage & & & $\begin{array}{l}1.126^{a} \\
(0.362)\end{array}$ & $\begin{array}{c}0.983^{b} \\
(0.395)\end{array}$ \\
\hline banks & $\begin{array}{c}0.008 \\
(0.043)\end{array}$ & $\begin{array}{l}-0.067 \\
(0.047)\end{array}$ & $\begin{array}{l}-0.075 \\
(0.047)\end{array}$ & $\begin{array}{c}-0.021 \\
(0.051)\end{array}$ \\
\hline stock markets & $\begin{array}{c}0.052^{c} \\
(0.030)\end{array}$ & $\begin{array}{c}0.052^{c} \\
(0.030)\end{array}$ & $\begin{array}{l}0.085^{a} \\
(0.029)\end{array}$ & $\begin{array}{c}0.081^{a} \\
(0.029)\end{array}$ \\
\hline GDPpc & $\begin{array}{l}0.358^{a} \\
(0.132)\end{array}$ & $\begin{array}{c}0.362^{a} \\
(0.133)\end{array}$ & $\begin{array}{c}0.174 \\
(0.166)\end{array}$ & $\begin{array}{c}0.213 \\
(0.167)\end{array}$ \\
\hline real exchange rate & & & $\begin{array}{c}-0.693 \\
(0.862)\end{array}$ & $\begin{array}{l}-0.557 \\
(0.875)\end{array}$ \\
\hline Full set of controls & yes & yes & yes & yes \\
\hline Exporting country FE & yes & yes & yes & yes \\
\hline Year FE & yes & yes & yes & yes \\
\hline HS6 product strata & yes & yes & yes & yes \\
\hline Observations & 175,481 & 175,481 & 121,157 & 121,157 \\
\hline \multicolumn{5}{|c|}{$\begin{array}{l}\text { Note: The dependent variable is the hazard rate on the US destination market for an export spell of product } k \text { from country } c \text { that } \\
\text { started at time } t_{z} \text {. All regressions are estimated using the Cox Proportional Hazard model (Cox, 1972) and control for country and } \\
\text { time fixed effects and allow for different baseline hazard rate across products by defining product } k \text { as strata variable. Additional } \\
\text { control variables include: the interaction between the bank credit over GDP in country } c \text { and the dependence of industry } j \text { on } \\
\text { external finance }\left(B C_{c, t_{z}} * E x F_{j}\right) \text {, the interaction between GDP per capita of country } c \text { and the distance to comparative advantage } \\
\left(G D P p c_{c, t_{z}} * D C A_{c k, t z_{z}}\right) \text {, and the real exchange rate }\left(R E R_{c, t z}\right) \text { and its interaction with the distance to comparative advantage } \\
\left(R E R_{c, t_{z}} * D C A_{c k, t_{z}}\right) \text {. Other variables are defined in Table III and Table V. Full set of controls corresponds to column }(6) \text { of } \\
\text { Table III. We report coefficients and not hazard ratios. Robust standard errors clustered at country*time }\left(c * t_{z}\right) \text { level are in } \\
\text { parentheses. } a, b \text {, and } c \text { denote statistical significance at the } 1 \%, 5 \% \text {, and } 10 \% \text { level, respectively. }\end{array}$} \\
\hline
\end{tabular}

the specification by adding interaction of countries' bank credit with industries' dependence on external finance $\left(B C_{c, t_{z}} * E x F_{j}\right)$. The significant disciplining effects of the US destination market and banking sector in the country of origin are not affected by this additional variable. The stock markets in the country of origin lack a significant disciplining effect on products not congruent with the comparative advantage also in this specification, confirming the results from Subsection 5.2. The estimated coefficient for the control itself (banks $\mathrm{x}$ dependence on external finance - $B C_{c, t_{z}} *$ $\left.E x F_{j}\right)$ is negative and significant, confirming the findings of Jaud, Kukenova, and Strieborny (2009). The direct effect of banks $\left(B C_{c, t_{z}}\right)$ on export survival remains insignificant while the direct effect of industry's dependence on external finance $\left(E x F_{j}\right)$ is captured by the strata effects.

Another bias might arise due to the high correlation between countries' financial and overall economic development. Rather than the disciplining effects of banks, our main interaction term (banks x distance to comparative advantage $-B C_{c, t_{z}} * D C A_{c k, t_{z}}$ ) may simply capture the effect of 
some unobservable features of rich countries that help them avoid using resources inefficiently for unpromising exports. In the second column of Table VII, in addition to exporting country's GDP $\left(G D P p c_{c, t_{z}}\right)$, we therefore also include its interaction with the distance to comparative advantage $\left(G D P p c_{c, t_{z}} * D C A_{c k, t_{z}}\right)$ to account for any direct and indirect effects of country's economic development on export performance. Despite the high correlation between financial and economic development, the coefficients for the distance to comparative advantage $\left(D C A_{c k, t_{z}}\right)$ and its interaction with banks $\left(B C_{c, t_{z}} * D C A_{c k, t_{z}}\right)$ remain positive and significant. ${ }^{40}$ Both the interaction of stock markets and distance to comparative advantage $\left(S t M_{c, t_{z}} * D C A_{c k, t_{z}}\right)$ and the interaction of the GDP per capita with the distance to comparative advantage $\left(G D P p c_{c, t_{z}} * D C A_{c k, t_{z}}\right)$ are insignificant. It seems to be indeed the disciplining impact of a well-developed banking system rather than some general feature of rich countries that prevents resource misallocation in form of attempted exports not corresponding to the exporting country's factor endowment.

In the third column of Table VII, we control for the level of real exchange rate of countries exporting their products to the USA. As countries develop both economically and financially, their currencies often appreciate due to the well-known Harrod-Balassa-Samuelson effect. The episodes of rapid financial development are also sometimes associated with inflows of foreign capital that can lead to currency appreciations. These developments could introduce bias with unclear sign into our regressions if changes in the currency levels affect exports of products that correspond to the comparative advantage of a given country differently from products that do not. The results in the third column of Table VII document the robustness of our main results to this alternative channel. Coefficients for both distance to comparative advantage and its interaction with banks remain significant with the expected positive sign. In contrast, the stock market interaction now becomes significant with the wrong sign. The result from Table VI where the other two stock market proxies were also sometimes significant with the wrong sign could thus be explained by some interplay between stock market development and real appreciations, for example during economic booms driven by inflows of foreign capital. ${ }^{41}$

In the fourth column of Table VII, we simultaneously control for all three alternative economic channels examined in columns (1) to (3). In particular, we include as control variables the interaction term between countries' banking sector development and industries' dependence on external finance $\left(B C_{c, t_{z}} * E x F_{j}\right)$, the interaction term between countries' economic development and the

$\overline{40}$ The strength of banking sector $\left(B C_{c, t_{z}}\right)$ and the GDP per capita $\left(G D P p c_{c, t_{z}}\right)$ are correlated at $61 \%$ in our sample. ${ }^{41}$ In terms of our simple model, the domestic stock markets could so heavily misallocate the excessive inflows of foreign capital that it became disproportionately easier for inefficient export projects to receive external funding $\left(\frac{\partial^{2} \phi(d, f)}{\partial d \partial f}>0\right)$ and the whole expression in Equation (7) could become negative. We leave the exploration of this possibility for further research. 
distance to comparative advantage $\left(G D P p c_{c, t_{z}} * D C A_{c k, t_{z}}\right)$, and the real exchange rate $\left(R E R_{c, t_{z}}\right)$ and its interaction with distance to comparative advantage $\left(R E R_{c, t_{z}} * D C A_{c k, t_{z}}\right)$. Our main results are robust also in this extended specification. Both distance to comparative advantage $\left(D C A_{c k, t_{z}}\right)$ and its interaction term with banking development in the exporting country (banks $\mathrm{x}$ distance to comparative advantage $\left.-B C_{c, t_{z}} * D C A_{c k, t_{z}}\right)$ remain positive and significant.

In the rest of this subsection, we look closer at the interplay between the channel examined in this paper and the traditional role banks and stock markets play in alleviating financial constraints. The role of financial constraints and access to external finance is particularly important in the case of a costly and investment-intensive activity like exporting (see, e.g., Beck, 2002, 2003; Jaud, Kukenova, and Strieborny, 2009, 2015) and could therefore affect the ability of banks in the exporting countries to enhance the disciplining impact of the US destination market. At the same time, there seem to be two differences in how the traditional channel from finance-trade literature and the channel explored in our paper operate. First, the research on alleviating financial constraints mostly focuses on how financial development promotes entry into exporting while our channel looks into impact on long-term export survival. Second, the traditional channel looks into alleviation of financial constraints via the general financial development while it seems to be only the banking sector that enhances the long-term discipline of the product markets in our channel. In the remainder of this section, we explore these issues in more detail.

The main focus of our paper is the role that banking sector plays in enhancing the disciplining impact of the product markets. In the first two columns of Table VIII, we explore whether the strength of this enhancing effect varies according to the severity of financial constraints firms face. Column (1) of Table VIII reports the results for the subset of exported products from industries that are in the bottom quartile of dependence on external finance. Column (2) of Table VIII reports results for the highly financially constrained industries from the top quartile of dependence on external finance. One could expect that external debtholders like banks in the exporting countries are better able to enhance the disciplining effect of the US destination market in industries where firms require a high level of external financing in the first place. And indeed, while the interaction term of banks and distance to comparative advantage has expected sign and is highly significant in column (2), it is insignificant in column (1). The coefficient capturing the direct effect of distance to comparative advantage is positive and significant in both column (1) and column (2). The higher magnitude of this coefficient in column (2) suggests that the disciplining effect of the US destination market might also be higher for the products from financially constrained industries. 
Table VIII: Banks, Stock Markets, Comparative Advantage and External Finance Dependence

\begin{tabular}{|c|c|c|c|c|c|c|}
\hline \multirow[t]{3}{*}{ Dep. Var: hazard rate } & $(1)$ & $(2)$ & $(3)$ & $(4)$ & \multirow{3}{*}{$\begin{array}{l}5) \\
\text { Hazar }\end{array}$} & \\
\hline & \multicolumn{2}{|c|}{$\begin{array}{c}\text { External finance } \\
\text { dependence }\end{array}$} & \multicolumn{2}{|c|}{$\begin{array}{c}\text { Distance to comp. } \\
\text { advantage }\end{array}$} & & f export entry \\
\hline & Low & High & Low & High & & \\
\hline distance to comparative advantage & $\begin{array}{l}0.046^{a} \\
(0.016)\end{array}$ & $\begin{array}{l}0.100^{a} \\
(0.024)\end{array}$ & & & $\begin{array}{r}-0.126^{a} \\
(0.012)\end{array}$ & $\begin{array}{r}-0.132^{a} \\
(0.013)\end{array}$ \\
\hline banks $\mathrm{x}$ dist. to comp. advantage & $\begin{array}{c}0.024 \\
(0.021)\end{array}$ & $\begin{array}{l}0.080^{b} \\
(0.034)\end{array}$ & & & $\begin{array}{l}-0.001 \\
(0.016)\end{array}$ & $\begin{array}{c}0.019 \\
(0.018)\end{array}$ \\
\hline stock markets $\mathrm{x}$ dist. to comp. advantage & $\begin{array}{c}0.006 \\
(0.019)\end{array}$ & $\begin{array}{l}-0.037 \\
(0.026)\end{array}$ & & & & $\begin{array}{l}-0.013 \\
(0.012)\end{array}$ \\
\hline banks $\mathrm{x}$ dep. on external finance & & & $\begin{array}{r}-0.292^{a} \\
(0.053)\end{array}$ & $\begin{array}{l}-0.243^{a} \\
(0.065)\end{array}$ & $\begin{array}{l}0.226^{a} \\
(0.035)\end{array}$ & $\begin{array}{l}0.208^{a} \\
(0.035)\end{array}$ \\
\hline banks & $\begin{array}{c}0.021 \\
(0.055)\end{array}$ & $\begin{array}{r}-0.080 \\
(0.067)\end{array}$ & $\begin{array}{l}0.134^{b} \\
(0.063)\end{array}$ & $\begin{array}{c}0.071 \\
(0.044)\end{array}$ & $\begin{array}{r}-0.089^{b} \\
(0.039)\end{array}$ & $\begin{array}{r}-0.132^{a} \\
(0.040)\end{array}$ \\
\hline stock markets & $\begin{array}{l}-0.008 \\
(0.039)\end{array}$ & $\begin{array}{l}0.072^{b} \\
(0.036)\end{array}$ & & & & $\begin{array}{l}0.016 \\
(0.027)\end{array}$ \\
\hline Full set of controls & yes & yes & yes & yes & yes & yes \\
\hline Exporting country FE & yes & yes & yes & yes & yes & yes \\
\hline Year FE & yes & yes & yes & yes & yes & yes \\
\hline HS6 product strata & yes & yes & yes & yes & yes & yes \\
\hline Observations & 48,158 & 50,504 & 48,495 & 47,876 & 165,190 & 144,912 \\
\hline $\begin{array}{l}\text { Note: The dependent variable is the hazard rate } \\
\text { at time } t_{z} \text {. In columns }(5) \text { and }(6) \text {, we replace the } \\
\text { regressions are estimated using the Cox Proportio } \\
\text { different baseline hazard rate across products by } \\
\text { of products from the bottom and the top quartil } \\
\text { results for subsamples of products from the bott } \\
\text { variables include: the interaction between the ba } \\
\left(B C_{c, t_{z}} * E x F_{j}\right) \text {, the interaction between GDP per } \\
\text { and the real exchange rate }\left(R E R_{c, t_{z}}\right) \text { and its inte } \\
\text { defined in Table III, Table V, and Table VII. Fu } \\
\text { hazard ratios. Robust standard errors clustered a } \\
\text { at the } 1 \%, 5 \% \text {, and } 10 \% \text { level, respectively. }\end{array}$ & $\begin{array}{l}\text { the US de } \\
\text { hazard rat } \\
\text { al Hazard } \\
\text { efining pro } \\
\text { of ISIC } 4 \\
m \text { and the } \\
\mathrm{k} \text { credit or } \\
\text { capita of c } \\
\text { action with } \\
\text { set of con }\end{array}$ & $\begin{array}{l}\text { tination } r \\
\text { of export } \\
\text { odel (Cox } \\
\text { luct } k \text { as } \\
\text { digit indu } \\
\text { top quart } \\
\text { er GDP il } \\
\text { untry } c \text { ar } \\
\text { the distan } \\
\text { rols corre }\end{array}$ & $\begin{array}{l}\text { arket for } \\
\text { exit with } \\
1972) \text { an } \\
\text { rata vari } \\
\text { ries depe } \\
\text { le of the } \\
\text { country } \\
\text { d the dist } \\
\text { e to com] } \\
\text { ponds to }\end{array}$ & $\begin{array}{l}\text { export sp } \\
\text { e hazard } \\
\text { ontrol for } \\
\text { e. Colum } \\
\text { ent on ex } \\
\text { tance to } \\
\text { nd the de } \\
\text { e to comp } \\
\text { ative adve } \\
\text { umn }(6)\end{array}$ & $\begin{array}{l}\text { f product } \\
\text { of entry } \\
\text { ntry and } \\
\text { l) and }(2) \\
\text { al finance } \\
\text { parative a } \\
\text { dence of } \mathrm{i} \\
\text { ive advan } \\
\text { ge (RER } \\
\text { able III. }\end{array}$ & $\begin{array}{l}\text { untry } c \text { that started } \\
\text { endent variable. All } \\
\text { effects and allow for } \\
\text { sults for subsamples } \\
\text { s (3) and (4) report } \\
\text { Additional control } \\
\text { on external finance } \\
P p c_{c, t_{z}} * D C A_{c k, t_{z}} \text {, } \\
\left.c k, t_{z}\right) \text {. Variables are } \\
\text { coefficients and not } \\
\text { atisticicificance }\end{array}$ \\
\hline
\end{tabular}

Again, deep stock markets in exporting countries do not seem to enhance the disciplining effect of the US destination market as the coefficient of the stock market interaction is insignificant for both financially constrained and unconstrained industries.

While the presence of financial constraints should make the firms and their managers more responsive to the disciplining impact of external debtholders like banks, the alleviation of these constraints via financial development might facilitate exports of all kinds of products including the less efficient ones. We explore this conjecture in columns (3) and (4) of Table VIII, which report the results for the subsamples of products from the bottom quartile and the top quartile of the distance to comparative advantage, respectively. The interaction term of countries' banking sector development with industries' dependence on external finance $\left(B C_{c, t_{z}} * E x F_{j}\right)$ has the expected negative sign and is significant in both columns. The results from the first four columns of Table VIII thus suggest that while being financially constrained matters for the disciplining channel explored in this paper, the standard channel from finance-trade literature works for all constrained industries independently on the alignment of their exports with the comparative advantage. 
Although there is some research on the importance of financial constraints for the long-term export survival (Jaud, Kukenova, and Strieborny, 2009, 2015), most of the literature on this traditional finance-trade channel focuses on how access to finance affects bilateral trade flows and/or how it helps financially constrained exporters to enter new destination markets (e.g., Minetti and Zhu, 2011; Becker, Chen, and Greenberg, 2013; Manova, 2013; Muûls, 2015). ${ }^{42}$ This is different from the channel explored in our paper where the issue of banking development enhancing the ultimate but slow-acting forces of competitive product markets naturally leads to empirical focus on the hazard rate of existing exports.

In order to explore the issue of export entry and still stay in the framework of duration analysis, we thus look at the "hazard rate" of products' entry rather than their exits in the last two columns of Table VIII. ${ }^{43}$ This means that all coefficients have now the opposite expected signs compared to the previous estimations. In column (5), we focus on the impact of banks alone. In column (6), we consider also the effect of the stock markets. In both specifications, the insignificant coefficient for our main interaction term $\left(B C_{c, t_{z}} * D C A_{c k, t_{z}}\right)$ suggests that the channel explored in our paper does not operate via the extensive margin of exports. This is consistent with our simple theoretical model where the agency costs influence termination of inefficient ongoing export projects but not the export entry. The result is also reassuring from the point of view of potential sample selection that we discuss in more detail in Subsection 6.1.

The result for the disciplining channel explored in this paper does not mean that banking development does not play a role for export entry in general. The interaction term between countries' banking sector development and industries' dependence on external finance $\left(B C_{c, t_{z}} *\right.$ $E x F_{j}$ ) has a positive and significant coefficient in both column (5) and (6), suggesting that banks disproportionately promote export entry in industries that do not generate enough internal funds relative to their investment needs. These results confirm the findings in existing literature about the important role banks play in promoting export entry by alleviating exporters' financial constraints.

In this section, we have provided ample evidence suggesting that disciplining channel examined in this paper operates only through strong banks and not through deep stock markets. This evidence is not likely to stem from a measurement problem. Similarly to the banking development, we have relied on standard and widely used empirical proxies also in the case of the stock markets development. Table XIV in the Appendix A reinforces this argument by confirming that the

\footnotetext{
$\overline{42}$ We are grateful to the editor for drawing our attention to this fact.

${ }^{43}$ We are grateful to the referee for suggesting this empirical specification that allows us to explore the issue of export entry within the empirical framework of duration analysis.
} 
traditional channel of financial institutions and markets promoting exports via easing the liquidity constraints does work in the case of stock markets. The coefficient for the interaction term of stock markets and dependence on external finance $\left(S t M_{c, t_{z}} * E x F_{j}\right)$ is negative and significant in all columns of Table XIV. This result is robust to controlling for our main channel as well as to controlling for the overall economic development in the exporting countries via the interaction term between GDP per capita and distance to comparative advantage. As predicted by theory and previous empirical work (e.g., Jaud, Kukenova, and Strieborny, 2009), deep stock markets indeed improve countries' export performance (decrease the hazard rate of export spells) especially for those industries that heavily depend on external finance. Our results thus do not imply that stock markets are not important for export performance in general. It is only the case of the disciplining channel examined in this paper where banks play a pivotal role. A further analysis of possible interplay between this novel channel and the traditional channel of financial development alleviating financial constraints could represent a fruitful area for further research.

\section{Robustness Tests}

In this section, we perform a series of additional regressions to confirm the robustness of our main results. As stock markets do not exert a significant disciplining effect on exports already in the previous specifications (as seen in Table V, Table VI, Table VII, Table VIII, and Table XIV), we focus on the robustness of the bank channel. The point of departure is column (6) of Table III.

\subsection{Sample Selection}

In the first two sections of this paper, we argued both verbally and formally that the mechanism in our paper works in the long term, affecting the termination rates of existing export projects that are inefficient but might generate managerial perks. However, one could certainly come up with an alternative theoretical framework where banks also prevent export entry of products not corresponding to the comparative advantage of the exporting country. One empirical implication of such theoretical scenario would be less entry into exporting of inefficient products from countries with a well-developed banking system. The sample of existing export spells examined in our duration analysis framework would be then subject to a possible selection bias. ${ }^{44}$

We first test the possibility of the sample selection directly, by examining the hazard rate of export entry rather than export exits in column (1) of Table IX. The expected coefficients have thus the opposite signs from our main estimations, similarly to the last two columns of

\footnotetext{
${ }^{44}$ We are grateful to the referee for making us aware of this possibility.
} 
Table VIII. While those two estimations examined the alternative channel from existing financetrade literature, column (1) of Table IX is based on our preferred specification from column (6) of Table III. Confirming the results from Table VIII, there is no evidence for sample selection. The interaction term between banks and distance to comparative advantage is insignificant in column (1) of Table IX, suggesting that export entry of inefficient products is not affected by the strength of the banking sector. Like in our model, banks enhance the disciplining impact of product markets only when it comes to the long-term survival of existing export projects. A possible explanation might be that government-run export agencies focus on export entry (Volpe and Carballo, 2008), possibly allowing some inefficient exports to evade the disciplining effect of non-governmental debtholders. ${ }^{45}$

While there does not seem to be any sample selection at the export entry, our results might still be driven by some influential outliers at the country level regarding banking development or the quality of export portfolio. In columns (2) and (3) of Table IX, we thus drop the observations from exporting countries in the bottom 5th and the top 5th percentile of banking development. In columns (4) and (5), we drop observations from countries with the worst and the best export portfolio, i.e. countries whose export portfolios are in the bottom 5 th and the top 5 th percentile as measured by the average distance to comparative advantage. Otherwise the estimations correspond to column (6) of Table III. The results remain qualitatively the same in all four columns and they do so also when we exclude the bottom and top 10th rather than 5th percentile (not reported). Finally, we provide some visual evidence. Figure 1 compares the export compositions of countries from the top and bottom quartiles of banking development. It shows that while the export composition of countries with a well-developed banking system does lean towards products close to their respective comparative advantage (which is to be expected given our results showing a higher hazard rate facing by inefficient exports from such countries), there is a sufficient overlap between the two distributions enabling estimation of our main interaction term $\left(B C_{c, t_{z}} * D C A_{c k, t_{z}}\right)$.

\footnotetext{
45 Görg, Henry, and Strobl (2008) provide some evidence that general government subsidies like R\&D grants promote also the intensive margin of exports. In either case, the product market competition arguably prevails in the long run as most countries lack resources to subsidize exports of non-competitive products indefinitely. Distortionary government interventions in exporting countries can therefore be expected to affect the short-term export dynamics more than the long-term export survival. We leave this issue for further research.
} 
Table IX: Robustness Checks I: Banks and Comparative Advantage

\begin{tabular}{|c|c|c|c|c|c|}
\hline \multirow{4}{*}{ Dep. Var: } & \multirow{4}{*}{$\begin{array}{c}(1) \\
\text { Product } \\
\text { introduction }\end{array}$} & $(2)$ & $(3)$ & (4) & $(5)$ \\
\hline & & \multicolumn{4}{|c|}{ Hazard rate } \\
\hline & & \multicolumn{2}{|c|}{ Financial development } & \multicolumn{2}{|c|}{ DCA of export portfolio } \\
\hline & & $\begin{array}{c}\text { Excl. } \\
\text { bottom 5th }\end{array}$ & $\begin{array}{l}\text { Excl. } \\
\text { top 5th }\end{array}$ & $\begin{array}{c}\text { Excl. } \\
\text { bottom 5th }\end{array}$ & $\begin{array}{l}\text { Excl. } \\
\text { top 5th }\end{array}$ \\
\hline \multirow[t]{2}{*}{ distance to comparative advantage } & $-0.122^{a}$ & $0.082^{a}$ & $0.089^{a}$ & $0.082^{a}$ & $0.081^{a}$ \\
\hline & $(0.012)$ & $(0.014)$ & $(0.015)$ & $(0.014)$ & $(0.014)$ \\
\hline \multirow[t]{2}{*}{ banks $\mathrm{x}$ dist. to comp. advantage } & -0.017 & $0.062^{a}$ & $0.054^{b}$ & $0.065^{a}$ & $0.063^{a}$ \\
\hline & $(0.016)$ & $(0.019)$ & $(0.025)$ & $(0.020)$ & $(0.019)$ \\
\hline \multirow[t]{2}{*}{ banks } & -0.021 & $-0.080^{c}$ & -0.039 & $-0.087^{b}$ & $-0.080^{c}$ \\
\hline & $(0.039)$ & $(0.043)$ & $(0.061)$ & $(0.043)$ & $(0.043)$ \\
\hline Full set of controls & yes & yes & yes & yes & yes \\
\hline Exporting country FE & yes & yes & yes & yes & yes \\
\hline Year FE & yes & yes & yes & yes & yes \\
\hline HS6 product strata & yes & yes & yes & yes & yes \\
\hline Observations & 165,190 & 189,450 & 175,349 & 180,813 & 189,897 \\
\hline
\end{tabular}

Note: The dependent variable is the hazard rate on the US destination market for an export spell of product $k$ from country $c$ that started at time $t_{z}$. In column (1), we replace the hazard rate of export exit with the hazard rate of entry as our dependent variable. All regressions are estimated using the Cox Proportional Hazard model (Cox, 1972) and control for country and time fixed effects and allow for different baseline hazard rate across products by defining product $k$ as strata variable. Variables are defined in Table III. Full set of controls corresponds to column (6) of Table III. In columns (2) and (3), we drop the observations from exporting countries in the bottom 5th and the top 5th percentile of banking development. In columns (4) and (5), we drop observations from exporting countries in the bottom 5 th and the top 5th percentile of the export portfolio quality as measured by the distance to comparative advantage. We report coefficients and not hazard ratios. Robust standard errors clustered at country*time $\left(c * t_{z}\right)$ level are in parentheses. $a, b$, and $c$ denote statistical significance at the $1 \%, 5 \%$, and $10 \%$ level, respectively.

Figure 1: Export Composition of Countries with Different Levels of Financial Development

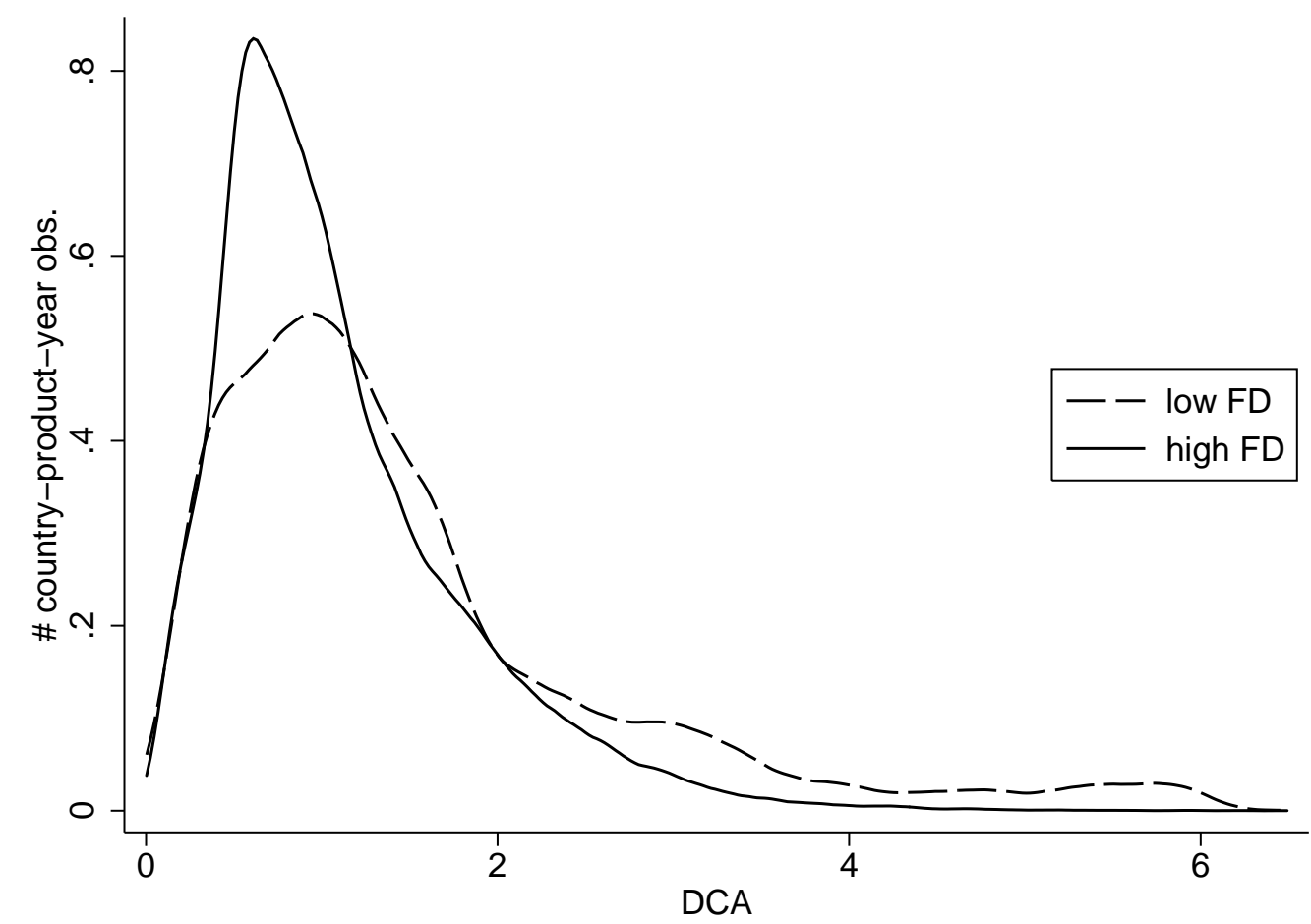




\subsection{Alternative Empirical Proxies and an Alternative Destination Market}

Table $\mathrm{X}$ examines the robustness of our main results to alternative measures of physical and human capital intensity (first column), alternative definitions of the distance to comparative advantage (second to eighth column), and an alternative destination market (last column).

When controlling for interaction terms between the exporting countries' factor endowments and the corresponding factor intensities at the sectoral level (physical capital x physical capital intensity $-\kappa_{c, t_{z}} * C a p I n t_{j}$, human capital x human capital intensity - $\left.h_{c, t_{z}} * H u m I n t_{j}\right)$, we generally rely on the measures of physical and human capital intensity from Braun (2003) as we prefer to stay as close as possible to existing literature in the case of variables that are merely controls in our context. As a robustness test, we use in column (1) of Table X instead our own measures of revealed factor intensity (RFI) used in the computation of distance to comparative advantage. The results remain qualitatively the same.

Columns (2) to (8) of Table $\mathrm{X}$ examine the robustness of our results to alternative ways of computing the distance to comparative advantage $\left(D C A_{c k, t_{z}}\right)$. In the second column, we replace the Euclidean distance with the absolute distance. The new formula for distance of product $k$ from comparative advantage of exporting country $c$ (Equation 8) now writes:

$$
D C A_{c k, t_{z}}=\left|\operatorname{std}\left(\kappa_{c, t_{z}}-\hat{\kappa}_{k, t_{z}}\right)\right|+\left|\operatorname{std}\left(h_{c, t_{z}}-\hat{h}_{k, t_{z}}\right)\right|
$$

Results remain qualitatively the same. In the third and fourth column of Table X, we add arable land per worker as a third production factor when computing the distance to comparative advantage. We use the Euclidean distance in column (3) and absolute distance in column (4). Adding the third production factor does not qualitatively change our results for either the direct effect of distance to comparative advantage $\left(D C A_{c k, t_{z}}\right)$ or the main interaction term between banks and distance to comparative advantage $\left(B C_{c, t_{z}} * D C A_{c k, t_{z}}\right)$.

In columns (5) to (8), we address the potential bias that could emerge due to the fact that for all trade flows from any given exporting country to the USA, the factor endowments of both the country of origin and the destination country enter the computation of our distance to comparative advantage measure. In columns (5) and (6), we drop the data from the country of origin $c$ when computing the distance to comparative advantage $\left(D C A_{c k, t_{z}}\right)$. In columns (7) and (8), we recompute $D C A_{c k, t_{z}}$ without data from the US destination market. Columns (5) and (7) report the results for recomputed Euclidean distance, while columns (6) and (8) report the results for 
Table X: Robustness Checks II: Banks and Comparative Advantage

\begin{tabular}{|c|c|c|c|c|c|c|c|c|c|}
\hline \multirow[t]{3}{*}{ Dep. Var: hazard rate } & \multirow{3}{*}{$\begin{array}{l}\text { (1) } \\
\text { Alt. } \\
\text { RFI }\end{array}$} & \multirow[t]{2}{*}{$(2)$} & \multirow{2}{*}{\multicolumn{2}{|c|}{$\begin{array}{l}(3) \\
\text { Incl. land }\end{array}$}} & \multirow{2}{*}{\multicolumn{2}{|c|}{$\begin{array}{l}(5) \\
\text { Excl. origin } \\
\text { country }\end{array}$}} & \multirow{2}{*}{\multicolumn{2}{|c|}{$\begin{array}{cc}(7) & (8) \\
\text { Excl. USA }\end{array}$}} & \multirow{3}{*}{$\begin{array}{c}(9) \\
\text { Germany }\end{array}$} \\
\hline & & & & & & & & & \\
\hline & & Abs. & Eucl. & Abs. & Eucl. & Abs. & Eucl. & Abs. & \\
\hline \multirow[t]{2}{*}{ dist. to comp. advantage } & $0.061^{a}$ & $0.053^{a}$ & $0.067^{a}$ & $0.038^{a}$ & $0.074^{a}$ & $0.049^{a}$ & $0.080^{a}$ & $0.054^{a}$ & $0.048^{a}$ \\
\hline & $(0.017)$ & $(0.009)$ & $(0.014)$ & $(0.008)$ & $(0.014)$ & $(0.010)$ & $(0.013)$ & $(0.009)$ & $(0.013)$ \\
\hline \multirow[t]{2}{*}{ banks $\mathrm{x}$ dist. to comp. advantage } & $0.083^{a}$ & $0.046^{a}$ & $0.080^{a}$ & $0.054^{a}$ & $0.063^{a}$ & $0.045^{a}$ & $0.063^{a}$ & $0.045^{a}$ & $0.045^{b}$ \\
\hline & $(0.019)$ & $(0.013)$ & $(0.019)$ & $(0.012)$ & $(0.019)$ & $(0.013)$ & $(0.019)$ & $(0.013)$ & $(0.019)$ \\
\hline \multirow[t]{2}{*}{ banks } & $-0.104^{b}$ & $-0.080^{c}$ & $-0.134^{a}$ & $-0.141^{a}$ & $-0.080^{c}$ & $-0.078^{c}$ & $-0.081^{c}$ & $-0.078^{c}$ & $-0.109^{b}$ \\
\hline & $(0.042)$ & $(0.042)$ & $(0.048)$ & $(0.049)$ & $(0.043)$ & $(0.042)$ & $(0.043)$ & $(0.042)$ & $(0.053)$ \\
\hline Full set of controls & yes & yes & yes & yes & yes & yes & yes & yes & yes \\
\hline Exporting country FE & yes & yes & yes & yes & yes & yes & yes & yes & yes \\
\hline Year FE & yes & yes & yes & yes & yes & yes & yes & yes & yes \\
\hline HS6 product strata & yes & yes & yes & yes & yes & yes & yes & yes & yes \\
\hline Observations & 211,643 & 191,078 & 191,078 & 191,078 & 190,490 & 190,490 & 191,078 & 191,078 & 153,939 \\
\hline \multicolumn{10}{|c|}{$\begin{array}{l}\text { Note: The dependent variable is the hazard rate on the US destination market for an export spell of product } k \text { from country } c \text { that started at } \\
\text { time } t_{z} \text {. All regressions are estimated using the Cox Proportional Hazard model (Cox, 1972) and control for country and time fixed effects and } \\
\text { allow for different baseline hazard rate across products by defining product } k \text { as strata variable. Variables are defined in Table III. In column } \\
\text { (1), we use alternative measures of physical and human capital intensity. In columns }(2) \text { to }(8) \text { we use alternative definitions of the distance to } \\
\text { comparative advantage. In column (9), we replace the USA with Germany as our destination market. Full set of controls corresponds to column } \\
\text { (6) of Table III. We report coefficients and not hazard ratios. Robust standard errors clustered at country*time }\left(c * t_{z}\right) \text { level are in parentheses. } \\
a, b \text {, and } c \text { denote statistical significance at the } 1 \%, 5 \% \text {, and } 10 \% \text { level, respectively. }\end{array}$} \\
\hline
\end{tabular}

recomputed absolute distance. As one can see from columns (5) to (8) of Table X, our main results are robust to exclusion of data from the country of origin and from the US destination market in computing the distance to comparative advantage $\left(D C A_{c k, t_{z}}\right)$.

Most of our estimations look into exports from 71 countries at different stages of financial development into the US destination market, allowing us to better distinguish between the impact of well-developed banks and highly competitive product market on termination of exports not corresponding to the comparative advantage of exporting country. At the beginning of Section 4, we discussed in more detail our choice of the destination market. In the column (9) of Table X, we test the robustness of our results to the use of an alternative destination market. We have chosen Germany, which has also a well-developed, competitive and large product market. Our results remain qualitatively the same, as they do in the case of the UK destination market (the latter not reported, results available upon request).

\subsection{Alternative Samples}

Table XI examines whether our results are not driven by specific groups of countries. In the first column of Table XI, we drop all observations from small island countries as they often specialize in exports of only a few products. ${ }^{46}$ The reported results are similar to those in the sixth column

\footnotetext{
46 The excluded microstate islands are The Dominican Republic, Haiti, Jamaica, Mauritius and Trinidad and Tobago.
} 
Table XI: Robustness Checks III: Banks and Comparative Advantage

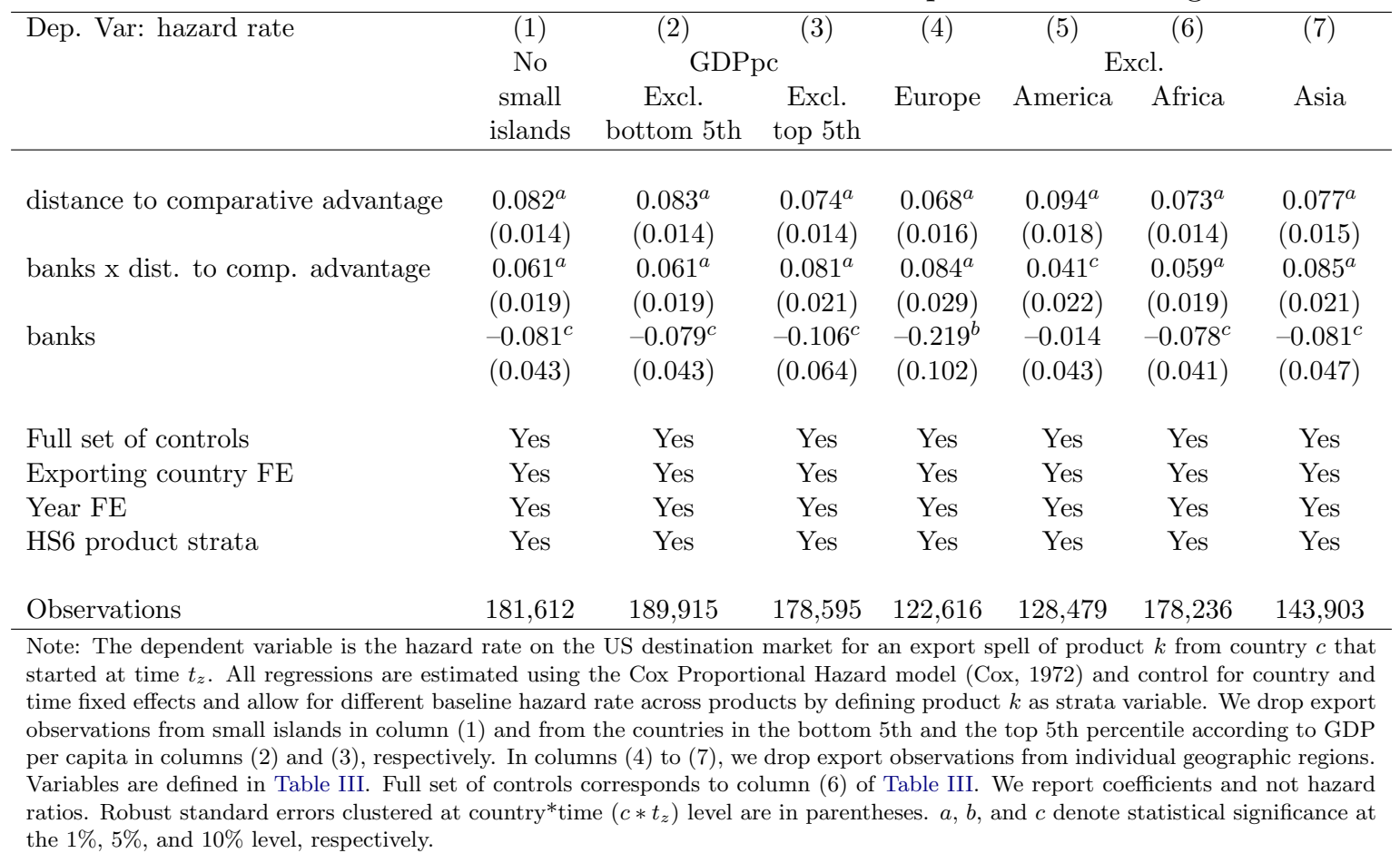

of Table III. Products far away from the comparative advantage of the exporting country still face higher hazard rate on the competitive US market as documented by a positive and significant coefficient for distance to comparative advantage $D C A_{c k, t_{z}}$. This pattern is stronger if the exporting country has a well-developed banking system (positive and significant coefficient for the main interaction term between banks and distance to comparative advantage $B C_{c, t_{z}} * D C A_{c k, t_{z}}$ ). Our results are thus not driven by small countries in the sample.

In column (2) and (3) of Table XI, we drop the 5th percentile of the poorest and richest exporting countries, as measured by the GDP per capita. Our results remain the same in both columns and they do so also when we exclude the bottom and top 10th rather than 5th percentile (not reported). In the last four columns we drop exports from individual geographical regions to the USA - Europe in column (4), America in column (5), Africa in column (6) and Asia in column (7). Again, our main results are not affected by this set of robustness checks.

\subsection{Econometric Robustness Tests}

We have also performed a battery of additional robustness tests that are important from the econometric point of view but might not considerably enhance the economic understanding of our channel. For space reasons, we report the results of these econometric tests in Online Appendix C. They include robustness tests regarding fixed effects, stratification and clustering of standard 
errors, robustness tests handling the issue of censoring, multiple spells and tied-spells termination events that are characteristic for the duration analysis, as well as additional estimations relaxing the hazard proportionality assumption made under the Cox model. ${ }^{47}$

\section{Conclusion}

This paper provides evidence for the allocative and disciplining role of finance. Banks do not promote exports in a sweeping non-discriminate way. They rather push exporters towards the optimal use of countries' factor endowments, in compliance with the idea of comparative advantage. A well-developed banking system in the exporting country can thus reinforce the disciplining impact of a competitive destination market. In this way, finance helps to prevent inefficient export patterns with positive consequences for national and international allocation of available resources.

To our knowledge, this is the first paper using disaggregated trade data to document that a well-functioning financial system can enhance the ultimate but often slow-acting discipline of product markets. Further research could investigate more in detail why banks seem to be more successful in this regard compared to stock and bond markets. Existing theories on disciplining role of debt and monitoring abilities of banks cited in this paper provide a possible economic rationale for this result. Compared to shareholders, creditors can also easier rely on the legal enforcement as their rights are usually more clearly defined and therefore better enforceable even by mediocre and poorly motivated courts (see, e.g., Harris and Raviv, 1990; Shleifer and Vishny, 1997). This is especially important in countries with insufficient judicial quality where the disciplining influence exercised by financial institutions and markets might be particularly needed. In these countries, it might also not be the general stock market development that makes the difference but rather the entry of foreign investors (Jaud, Kukenova, and Strieborny, 2016).

Another venue for further research could involve exploiting the bilateral character of the highly disaggregated data on international trade to distinguish between the impact of financial and product markets also in other contexts than the one explored in this paper.

\footnotetext{
47 A reader interested in the background of the performed robustness tests can consult various papers cited in the Online Appendix (Breslow, 1974; Efron, 1988; Moffitt and Rendall, 1995; Bertrand, Duflo, and Mullainathan, 2004; Cameron, Gelbach and Miller, 2006; Araujo, Mion, and Ornelas, 2014).
} 


\section{Appendix}

\section{Appendix A - Additional Tables}

Table XII: Examples from the Harmonized System (HS) Product Classification

\begin{tabular}{|c|c|c|c|}
\hline $\begin{array}{l}\text { Chapter } \\
\text { HS 2-digit code }\end{array}$ & $\begin{array}{l}\text { Heading } \\
\text { HS 4-digit code }\end{array}$ & $\begin{array}{l}\text { Sub-heading } \\
\text { HS 6-digit code }\end{array}$ & Description \\
\hline \multirow[t]{5}{*}{61} & & & $\begin{array}{l}\text { Articles of apparel \& clothing accessories-knitted or } \\
\text { crocheted }\end{array}$ \\
\hline & 61.06 & & Women's or girls' blouses \& shirts, knit or crocheted \\
\hline & & 6106.10 & $\begin{array}{l}\text { Women's or girls' blouses, shirts, of cotton, knitted or } \\
\text { crocheted }\end{array}$ \\
\hline & & 6106.20 & $\begin{array}{l}\text { Women's blouses, shirts, of man-made fibres, knitted } \\
\text { or crocheted }\end{array}$ \\
\hline & & 6106.90 & $\begin{array}{l}\text { Women's or girls, blouses, shirts, of other textile ma- } \\
\text { terials }\end{array}$ \\
\hline \multirow[t]{7}{*}{84} & & & $\begin{array}{l}\text { Nuclear reactors, boilers, machinery \& mechanical ap- } \\
\text { pliances, computers }\end{array}$ \\
\hline & 84.50 & & Washing machines, household or laundry-type \\
\hline & & 8450.11 & $\begin{array}{l}\text { Fully-automatic washing machines, dry linen capacity } \\
\text { not exceeding } 10 \mathrm{~kg}\end{array}$ \\
\hline & & 8450.12 & $\begin{array}{l}\text { Machines, with built-in centrifugal drier, capacity not } \\
\text { exceeding } 10 \mathrm{~kg}\end{array}$ \\
\hline & & 8450.19 & $\begin{array}{l}\text { Other washing machines, each of a dry linen capacity } \\
\text { not exceeding } 10 \mathrm{~kg}\end{array}$ \\
\hline & & 8450.20 & $\begin{array}{l}\text { Washing machines, each of a dry linen capacity ex- } \\
\text { ceeding } 10 \mathrm{~kg}\end{array}$ \\
\hline & & 8450.90 & Parts of household or laundry-type washing machines \\
\hline
\end{tabular}

Note: Harmonized System (HS) of tariff nomenclature is an internationally standardized system of names and numbers to classify traded products.

Table XIII: Banks and Bond Markets

\begin{tabular}{|c|c|c|c|c|c|c|c|c|c|}
\hline Dep. Var: hazard rate & (1) & $(2)$ & $(3)$ & $(4)$ & $(5)$ & (6) & (7) & $(8)$ & $(9)$ \\
\hline \multirow[t]{2}{*}{ distance to comparative advantage } & $0.068^{a}$ & $0.077^{a}$ & $0.054^{a}$ & $0.080^{a}$ & $0.109^{a}$ & $0.081^{a}$ & $0.081^{a}$ & $0.116^{a}$ & $0.084^{a}$ \\
\hline & $(0.018)$ & $(0.013)$ & $(0.017)$ & $(0.016)$ & $(0.011)$ & $(0.016)$ & $(0.015)$ & $(0.010)$ & $(0.015)$ \\
\hline banks $\mathrm{x}$ dist. to comp. adv. & $0.047^{b}$ & & $0.037^{c}$ & $0.055^{a}$ & & $0.054^{b}$ & $0.054^{a}$ & & $0.056^{a}$ \\
\hline \multirow[t]{2}{*}{ banks } & -0.052 & & -0.041 & $-0.068^{c}$ & & -0.038 & -0.060 & & $-0.075^{c}$ \\
\hline & $(0.040)$ & & $(0.039)$ & $(0.041)$ & & $(0.049)$ & $(0.041)$ & & $(0.043)$ \\
\hline dom. private bonds $\mathrm{x}$ dist. to comp. adv. & & $0.107^{a}$ & $0.092^{b}$ & & & & & & \\
\hline \multirow[t]{2}{*}{ domestic private bonds to GDP } & & -0.075 & -0.058 & & & & & & \\
\hline & & $(0.109)$ & $(0.113)$ & & & & & & \\
\hline \multirow[t]{2}{*}{ inter. private bonds $\mathrm{x}$ dist. to comp. adv. } & & & & & 0.075 & -0.005 & & & \\
\hline & & & & & $(0.052)$ & $(0.066)$ & & & \\
\hline \multirow[t]{2}{*}{ international private bonds to GDP } & & & & & $0.261^{c}$ & $0.372^{a}$ & & & \\
\hline & & & & & $(0.140)$ & $(0.139)$ & & & \\
\hline \multirow[t]{2}{*}{ nonfin. inter. bonds $\mathrm{x}$ dist. to comp. adv. } & & & & & & & & -0.005 & -0.176 \\
\hline & & & & & & & & $(0.201)$ & $(0.209)$ \\
\hline nonfinancial international bonds to GDP & & & & & & & & $(0.518)$ & $(0.530)$ \\
\hline Full set of controls & Yes & Yes & Yes & Yes & Yes & Yes & Yes & Yes & Yes \\
\hline Exporting country FE & Yes & Yes & Yes & Yes & Yes & Yes & Yes & Yes & Yes \\
\hline Year FE & Yes & Yes & Yes & Yes & Yes & Yes & Yes & Yes & Yes \\
\hline HS6 product strata & Yes & Yes & Yes & Yes & Yes & Yes & Yes & Yes & Yes \\
\hline Observations & 127,260 & 127,260 & 127,260 & 158,291 & 158,291 & 158,291 & 168,113 & 168,113 & 168,113 \\
\hline
\end{tabular}

Note: The dependent variable is the hazard rate on the US destination market for an export spell of product $k$ from country $c$ that started at time $t_{z}$. All regressions are estimated using the Cox Proportional Hazard model (Cox, 1972) and control for country and time fixed effects. Estimations also allow for different baseline hazard rate across HS6 products by defining product $k$ as strata variable. Additional control variables include the interaction between three proxies of the strength of bond markets in the exporting country and the distance to comparative advantage. These three proxies are domestic private bonds (including bonds issued by banks) over GDP, international private bonds (including bonds issued by banks) over GDP and nonfinancial international bonds (bonds issued by non-financial firms only) over GDP. Other variables are defined in Table III. Full set of controls corresponds to column (6) of Table III. We report coefficients and not hazard ratios. Robust standard errors clustered at country*time $\left(c * t_{z}\right)$ level are in parentheses. $a, b$, and $c$ denote statistical significance at the $1 \%, 5 \%$, and $10 \%$ level, respectively. 
Table XIV: Stock Markets, Comparative Advantage and External Finance Dependence

\begin{tabular}{|c|c|c|c|c|}
\hline Dep. Var: hazard rate & $(1)$ & $(2)$ & $(3)$ & $(4)$ \\
\hline \multirow{2}{*}{ distance to comparative advantage } & $0.102^{a}$ & -0.022 & $0.113^{a}$ & 0.035 \\
\hline & $(0.010)$ & $(0.071)$ & $(0.011)$ & $(0.081)$ \\
\hline \multirow{2}{*}{ stock markets $\mathrm{x}$ distance to comparative advantage } & -0.006 & -0.014 & -0.008 & -0.012 \\
\hline & $(0.011)$ & $(0.012)$ & $(0.013)$ & $(0.013)$ \\
\hline \multirow[t]{2}{*}{ stock markets $\mathrm{x}$ dependence on external finance } & $-0.172^{a}$ & $-0.176^{a}$ & $-0.209^{a}$ & $-0.212^{a}$ \\
\hline & $(0.028)$ & $(0.028)$ & $(0.031)$ & $(0.031)$ \\
\hline \multirow[t]{2}{*}{ GDPpc $\mathrm{x}$ distance to comparative advantage } & & $0.014^{c}$ & & 0.009 \\
\hline & & $(0.008)$ & & $(0.009)$ \\
\hline \multirow[t]{2}{*}{ stock markets } & $0.076^{a}$ & $0.087^{a}$ & $0.088^{a}$ & $0.093^{a}$ \\
\hline & $(0.029)$ & $(0.030)$ & $(0.032)$ & $(0.032)$ \\
\hline \multirow[t]{2}{*}{ GDPpc } & 0.210 & 0.195 & $0.271^{b}$ & $0.262^{b}$ \\
\hline & $(0.132)$ & $(0.133)$ & $(0.133)$ & $(0.133)$ \\
\hline Full set of controls & yes & yes & yes & yes \\
\hline Exporting country FE & yes & yes & yes & yes \\
\hline Year FE & yes & yes & yes & yes \\
\hline ISIC4 industry strata & yes & yes & & \\
\hline HS6 product strata & & & yes & yes \\
\hline Observations & 182,592 & 182,592 & 182,592 & 182,592 \\
\hline \multicolumn{5}{|c|}{$\begin{array}{l}\text { Note: The dependent variable is the hazard rate on the US destination market for an export spell of product } k \text { from country } \\
c \text { that started at time } t_{z} \text {. All regressions are estimated using the Cox Proportional Hazard model (Cox, 1972) and control for } \\
\text { country and time fixed effects. Estimations also allow for different baseline hazard rate across industries (columns } 1 \text { to } 2) \text { and } \\
\text { across products (columns } 3 \text { to } 4 \text { ) by defining industry } j \text { and product } k \text { as strata variables. Additional control variables include } \\
\text { the interaction between the development of stock markets in country } c \text { and the dependence of industry } j \text { on external finance } \\
\text { (stock markets x dependence on external finance }-S t M_{c, t_{z}} * E x F_{j} \text { ), the interaction between the GDP per capita of country } c \\
\text { and the distance to comparative advantage }\left(G D P p c_{c, t_{z}} * D C A_{c k, t_{z}} \text { ). Other variables are defined in Table III and Table V. Full }\right. \\
\text { set of controls corresponds to column }(6) \text { of Table III. We report coefficients and not hazard ratios. Robust standard errors } \\
\text { clustered at country*time }\left(c * t_{z}\right) \text { level are in parentheses. } a, b \text {, and } c \text { denote statistical significance at the } 1 \%, 5 \% \text {, and } 10 \% \\
\text { level, respectively. }\end{array}$} \\
\hline
\end{tabular}

Appendix B - Full Sample of Countries Exporting to the USA

Argentina; Australia; Austria; Bangladesh; Benin; Bolivia; Brazil; Cameroon; Canada; Chile; China; Colombia; Congo; Costa Rica; Denmark; Dominican Republic; Ecuador; Egypt; El Salvador; Finland; France; Gambia; Germany; Ghana; Greece; Guatemala; Haiti; Honduras; India; Indonesia; Ireland; Italy; Jamaica; Japan; Jordan; Kenya; Korea; Malawi; Malaysia; Mali; Mauritius; Mexico; Mozambique; Nepal; Netherlands; New Zealand; Nicaragua; Niger; Norway; Pakistan; Panama; Paraguay; Peru; Philippines; Portugal; Rwanda; Senegal; Spain; Sri Lanka; Sweden; Switzerland; Thailand; Togo; Trinidad and Tobago; Tunisia; Turkey; United Kingdom; Uruguay; Venezuela; Zambia; Zimbabwe.

\section{References}

Aghion, P., Dewatripont, M., and Rey, P. (1999) Competition, financial discipline and growth, Review of Economic Studies 66, 825-852.

Ai, C. and Norton, E. C. (2003) Interaction terms in logit and probit models, Economics Letters 80, 123-129.

Allen, F. (1990) The market for information and the origin of financial intermediaries, Journal of Financial Intermediation 1(1), 3-30.

Allen, F. (1993) Stock markets and resource allocation, in: C. Mayer and X. Vives (eds.), Capital Markets and Financial Intermediation, Cambridge University Press, Cambridge, U.K., pp. 81-108.

Amiti, M. and Weinstein, D. E. (2011) Exports and financial shocks, Quarterly Journal of Economics 126(4), 1841-1877.

Araujo, L., Mion, G., and Ornelas, E. (2014) Institutions and export dynamics, mimeo, London School of Economics. 
Balassa, B. (1965) Trade liberalisation and "revealed" comparative advantage, Manchester School 33(2), 99-123.

Beck, T. (2002) Financial development and international trade: Is there a link?, Journal of International Economics 57, 107-131.

Beck, T. (2003) Financial dependence and international trade, Review of International Economics 11(2), 296-316.

Beck, T., Demirgüç-Kunt, A., and Levine, R. (2000) A new database on financial development and structure, World Bank Economic Review 14, 597-605.

Beck, T. and Levine, R. (2002) Industry growth and capital allocation: Does having a marketor bank-based system matter?, Journal of Financial Economics 64, 147-180.

Becker, B., Chen, J., and Greenberg, D. (2013) Financial development, fixed costs, and international trade, Review of Corporate Finance Studies 2(1), 1-28.

Bekaert, G., Harvey, C. R., Lundblad, C., and Siegel, S. (2007) Global growth opportunities and market integration, Journal of Finance 62(3), 1081-1137.

Berger, D., Easterly, W., Nunn, N., and Satyanath, S. (2013) Commercial imperialism? Political influence and trade during the Cold War, American Economic Review 103(2), 863-896.

Berger, P. G., Ofek, E., and Yermack, D. L. (1997) Managerial entrenchment and capital structure decisions, Journal of Finance 52(4), 1411-1438.

Berman, N. and Héricourt, J. (2010) Financial factors and the margins of trade: Evidence from cross-country firm-level data, Journal of Development Economics 93(2), 206-217.

Bernard, A. B. and Jensen, J. B. (1995) Exporters, jobs and wages in U.S. manufacturing, 1976-87, in: M. N. Baily, P. C. Reiss, and C. Winston (eds.), Brookings Papers on Economic Activity: Microeconomics, Volume 1995, Brooking Institutions Press, Washington DC, pp. 67-119.

Bertrand, M., Duflo, E., and Mullainathan, S. (2004) How much should we trust differences-in-differences estimates? Quarterly Journal of Economics 119(1), 249-275.

Bertrand, M., and Mullainathan, S. (2003) Enjoying the quiet life? Managerial behavior following anti-takeover legislation, Journal of Political Economy 111(5), 1043-1075.

Besedes, T. (2013) The role of NAFTA and returns to scale in export duration, CESifo Economic Studies 59(2), 306-336.

Besedes, T., and Prusa, T. J. (2006a) Ins, outs, and the duration of trade, Canadian Journal of Economics 39(1), 266-295.

Besedes, T., and Prusa, T. J. (2006b) Product differentiation and duration of US import trade, Journal of International Economics 70, 339-358.

Besedes, T., and Prusa, T. J. (2011) The role of extensive and intensive margins and export growth, Journal of Development Economics 96, 371-379.

Besedes, T., Kim, B.-C., and Lugovskyy, V. (2014) Export growth and credit constraints, European Economic Review 70, 350-370.

Bhagwati, J. N. (1972) The Heckscher-Ohlin theorem in the multi-commodity case, Journal of Political Economy 80(5), 1052-1055.

Bhattacharya, S. and Pfleiderer, P. (1985) Delegated portfolio management, Journal of Economic Theory 36(1), 1-25.

Boyd, J. H. and Prescott, E. C. (1986) Financial intermediary-coalitions, Journal of Economic Theory 38(2), 211-232.

Brambilla, I., Lederman, D., and Porto, G. (2010) Exports, export destinations, and skills, American Economic Review 102(7), 3406-3488.

Braun, M. (2003) Financial contractibility and asset hardness, mimeo, University of California Los Angeles.

Brenton, P., Cadot, O., and Pierola M. D. (2012) Pathways to African export sustainability, World Bank, Washington DC.

Brenton, P., Saborowski, C., and von Uexkull, E. (2010) What explains the low survival rate of developing country export flows?, World Bank Economic Review 24(3), 474-499.

Breslow, N. (1974) Covariance analysis of censored survival data, Biometrics, 89-99.

Bricongne, J.-C., Fontagné, L., Gaulier, G., Taglioni, D., and Vicard, V. (2010) Firms and the 
global crisis: French exports in the turmoil, ECB Working Paper No. 1245.

Cadot, O., Tumurchudur, B., and Shirotori, M. (2009) Revealed factor intensity indices at the product level, mimeo, United Nations Conference on Trade and Development.

Cadot, O., Carrère, C., and Strauss-Kahn, V. (2011) Export diversification: What's behind the hump?, Review of Economics and Statistics 93(2), 590-605.

Cadot, O., Iacovone, L., Pierola, M. D., and Rauch, F. (2013) Success and failure of African exporters, Journal of Development Economics 101, 284-296.

Carballo, J. and Volpe Martincus, C. (2008) Survival of new exporters in developing countries: Does it matter how they diversify?, Inter-American Development Bank Working Paper No. 9291.

Carrere, C. and Strauss-Khan, V. (2012) Exports dynamics: Raising developing countries exports survival through experience, FERDI Working Paper No. P35-A.

Cameron, A. C., Gelbach, J. B., and Miller, D. L. (2006) Robust inference with multi-way clustering, NBER Technical Working Paper No. 327.

Cameron, A. C. and Trivedi, P. K. (2005) Microeconometrics: Methods and applications., Cambridge University Press, New York.

Cassey, A. and Schmeiser, K. (2010) The agglomeration of exporters by destination, FREIT Working Paper No. 233.

Cihak, M., Demirgüç-Kunt, A., Feyen, E., and Levine, R. (2012) Benchmarking financial systems around the world, World Bank Policy Research Working Paper No. 6175.

Chor, D. and Manova, K. (2012) Off the cliff and back? Credit conditions and international trade during the global financial crisis, Journal of International Economics 87, 117-133.

Colla, P., Ippolito, F., and Li, K. (2013) Debt specialization, Journal of Finance 68(5), 2117-2141.

Costinot, A. (2009) An elementary theory of comparative advantage, Econometrica 77(4), 1165-1192.

Costinot, A., Donaldson, D., and Komunjer, I. (2012) What goods do countries trade? A Quantitative Exploration of Ricardo's Ideas, Review of Economic Studies 79, 581-608.

Cox, D. R. (1972) Regression models and life tables, Journal of the Royal Statistical Society, Series B 34(2), 187-220.

Deardorff, A. V. (1979) Weak links in the chain of comparative advantage, Journal of International Economics 9, 197-209.

Denis, D. J. and Mihov, V. T. (2003) The choice among bank debt, non-bank private debt, and public debt: Evidence from new corporate borrowings, Journal of Financial Economics 70, $3-28$.

Diamond, D. (1984) Financial intermediation and delegated monitoring, Review of Economic Studies 51(3), 393-414.

Do, Q.-T. and Levchenko, A. A. (2007) Comparative advantage, demand for external finance, and financial development, Journal of Financial Economics 86, 796-834.

Dornbusch, R., Fischer, S., and Samuelson, P. A. (1977) Comparative advantage, trade, and payments in a Ricardian model with a continuum of goods, American Economic Review 67, $823-839$.

Dornbusch, R., Fischer, S., and Samuelson, P. A. (1980) Heckscher-Ohlin trade theory with a continuum of goods, Quarterly Journal of Economics 95(2), 203-224.

Eaton, J. and Kortum, S. (2002) Technology, geography, and trade, Econometrica 70(5), 1741-1779.

Efron, B. (1988) Logistic regression, survival analysis, and the Kaplan-Meier curve, Journal of the American Statistical Association 83(402), 414-425.

Fama, E. F. (1985) What's different about banks?, Journal of Monetary Economics 15, 29-39.

Fisman, R. and Love, I. (2004) Financial development and intersectoral allocation: A New Approach, Journal of Finance 59(6), 2785-2807.

Frias, J., Kaplan, D., and Verhoogen, E. (2009) Exports and wage premia: Evidence from Mexican employer-employee data, mimeo, Columbia University.

Fugazza, M. and Molina, A.-C. (2011) On the determinants of exports survival, UNCTAD Blue Series Papers No. 47, United Nations Conference on Trade and Development.

Gaulier, G. and Zignago, S. (2010) BACI: International trade database at the product level. The 
1994-2007 version, CEPII Working Paper No. 2010-23.

Giroud, X. and Mueller, H. M. (2010) Does corporate governance matter in competitive industries?, Journal of Financial Economics 95, 312-331.

Giroud, X. and Mueller, H. M. (2011) Corporate governance, product market competition, and equity prices, Journal of Finance 66(2), 563-600.

Gomes, A. and Phillips, G. (2012) Why do public firms issue private and public securities?, Journal of Financial Intermediation 21, 619-658.

Görg, H., Henry, M., and Strobl, E. (2008) Grant support and exporting activity, Review of Economics and Statistics 90(1), 168-174.

Greenaway, D., Guariglia, A., and Kneller, R. (2007) Financial actors and exporting decisions, Journal of International Economics 73, 377-395.

Grossman, S. and Stiglitz, J. (1980) On the impossibility of informationally efficient markets, American Economic Review 70(3), 393-408.

Grossman, S., and Hart, O. (1982) Corporate financial structure and managerial incentives, in: J. McCall (ed.), The Economics of Information and Uncertainty, University of Chicago Press, Chicago.

Harris, M. and Raviv, A. (1990) Capital structure and the informational role of debt, Journal of Finance 45(2), 321-349.

Harris, M. and Raviv, A. (1991) The theory of capital structure, Journal of Finance 46(1), $297-355$.

Hart, O. (1983) The market mechanism as an incentive scheme, Bell Journal of Economics 14(2), $366-382$.

Hart, O. and Moore, J. (1995) Debt and seniority: An analysis of the role of hard claims in constraining management, American Economic Review 85(3), 567-585.

Hausmann R., Hwang, J., and Rodrik, D. (2007) What you export matters, Journal of Economic Growth 12(1), 1-25.

Hess, W. and Persson, M. (2012) The duration of trade revisited: Continuous-time vs. discrete-time hazards, Empirical Economics 43, 1083-1107.

Hicks, J. (1935) Annual survey of economic theory: The theory of monopoly, Econometrica 3, $1-20$.

Holmstrom, B. and Tirole, J. (1993) Market liquidity and performance monitoring, Journal of Political Economy 101(4), 678-709.

Hosmer, D. W. Jr., Lemeshow, S., and May, S. (2008) Applied survival analysis: Regression modeling of time to event data, 2th edition, John Wiley and Sons Inc, Hoboken.

Jaud, M., Kukenova, M., and Strieborny, M. (2009) Financial dependence and intensive margin of trade, PSE Working Paper No. 2009-35.

Jaud, M., Kukenova, M., and Strieborny, M. (2015) Financial development and sustainable exports: Evidence from firm-product data, World Economy 38(7), 1090-1114.

Jaud, M., Kukenova, M., and Strieborny, M. (2016) Stock market liberalizations and export dynamics, mimeo, Lund University.

Jensen, M. C. (1986) Agency costs of free cash flow, corporate finance, and takeovers, American Economic Review 76(2), 323-329.

Jensen, M. C. (1993) The modern industrial revolution, exit, and the failure of internal control systems, Journal of Finance 48(3), 831-880.

Jensen, M. C. and Meckling, W. H. (1976) Theory of the firm: Managerial behavior, agency costs and ownership structure, Journal of Financial Economics 3, 305-360.

Jones, R. W. (1956-1957) Factor proportions and the Heckscher-Ohlin theorem, Review of Economic Studies 24(1), 1-10.

Ju, J. and Wei, S.--J. (2005) Endowment versus finance: A wooden barrel theory of international trade, CEPR Discussion Paper No. 5109.

Kiefer, N. (1988) Economic duration data and hazard functions, Journal of Economic Literature 2(2), 646-679.

Koenig, P. (2009) Agglomeration and the export decisions of French firms, Journal of Urban 
Economics 66(3), 186-195.

Lang, L., Ofek, E., and Stulz, R. M. (1996) Leverage, investment, and firm growth, Journal of Financial Economics 40, 3-29.

Leibenstein, H. (1966) Allocative efficiency vs. "X-Efficiency", American Economic Review 56(3), $392-415$.

Levine, R. (2005) Finance and growth: Theory and evidence, in: P. Aghion and S. Durlauf (eds.), Handbook of Economic Growth, North Holland, Amsterdam, pp. 865-934.

Levchenko, A. A., Lewis, L. T., and Tesar, L. L. (2011) The role of trade finance in the U.S. trade collapse: A skeptic's view, in: J.-P. Chauffour and M. Malouche (eds.), Trade Finance During the Great Trade Collapse, World Bank, Washington DC, pp. 133-147.

Lin, C., Ma, Y., Malatesta, P., and Xuan, Y. (2013) Corporate ownership structure and the choice between bank debt and public debt, Journal of Financial Economics 109, 517-534.

Love, I. (2003) Financial development and financing constraints: International evidence from the structural investment model, Review of Financial Studies 16(3), 765-791.

Machlup, F. (1967) Theories of the firm: Marginalist, behavioral, managerial, American Economic Review 57(1), 1-33.

Manova, K. (2008) Credit constraints, equity market liberalizations and international trade, Journal of International Economics 76, 33-47.

Manova, K. (2013) Credit constraints, heterogeneous firms, and international trade, Review of Economic Studies 80, 711-744.

Manova, K, Wei, S.--J., and Zhang, Z. (2015) Firm exports and multinational activity under credit constraints, Review of Economics and Statistics 97(3), 574-588.

Merton, R. (1987) A simple model of capital market equilibrium with incomplete information, Journal of Finance 42(3), 483-510.

Minetti, R. and Zhu, S. C. (2011) Credit constraints and firm export: Microeconomic evidence from Italy, Journal of International Economics 83, 109-125.

Mion, G. and Opromolla, L. D. (2011) Managers' mobility, trade status, and wages, CEPR Discussion Paper No. 8230.

Moffitt, R. A. and Rendall, M. S. (1995) Cohort trends in the lifetime distribution of female family headship in the United States, 1968-1985, Demography 32, 407-424.

Morellec, E., Valta P., and Zhdanov, A. (2015) Financing investment: The choice between bonds and bank loans, Management Science 61(11), 2580-2602.

Morrow, P. M. (2010) Ricardian-Heckscher-Ohlin comparative advantage: Theory and evidence, Journal of International Economics 82(2), 137-151.

Moulton, B. R. (1986) Random group effects and the precision of regression estimates, Journal of Econometrics 32(3), 385-397.

Moulton, B. R. (1990) An illustration of a pitfall in estimating the effects of aggregate variables on micro unit, Review of Economics and Statistics 72(2), 334-38.

Muûls, M. (2015) Exporters, importers and credit constraints, Journal of International Economics 95, 333-343.

Nickell, S. J. (1996) Competition and corporate performance, Journal of Political Economy 104(4), 724-746.

Nitsch, V. (2009) Die Another Day: Duration in German import trade, Review of World Economics 145(1), 133-154.

Nunn, N. and Trefler, D. (2014) Domestic institutions as a source of comparative advantage, in: G. Gopinath, E. Helpman, and K. Rogoff (eds.), Handbook of International Economics, Volume 4, North Holland, Amsterdam, pp. 263-315.

Obashi, A. (2010) Stability of production networks in East Asia: Duration and survival of trade, Japan and the World Economy 22, 21-30.

Paravisini, D., Rappoport,V., Schnabl, P., and Wolfenzon, D. (2015) Dissecting the effect of credit supply on trade: Evidence from matched credit-export data, Review of Economic Studies 82, 333-359.

Prentice, R. and Gloeckler, L. (1978) Regression analysis of grouped survival data with application 
to breast cancer data, Biometrics 34(1), 57-67.

Raddatz, C. (2006) Liquidity needs and vulnerability to financial underdevelopment, Journal of Financial Economics 80(3), 677-722.

Raith, M. (2003) Competition, risk, and managerial incentives, American Economic Review 93(4), 1425-1436.

Rajan, R. G. and Zingales, L. (1998) Financial dependence and growth, American Economic Review 88(3), 559-86.

Ramakrishnan, R. T. S. and Thakor, A. (1984) Information reliability and a theory of financial intermediation, Review of Economic Studies 51(3), 415-32.

Romalis, J. (2004) Factor proportions and the structure of commodity trade, American Economic Review 94(1), 67-97.

Scharfstein, D. (1988) The disciplinary role of takeovers, Review of Economic Studies 55(2), 185-199.

Schmidt, K. M. (1997) Managerial incentives and product market competition, Review of Economic Studies 64, 191-213.

Schott, P. K. (2003) One size fits all? Heckscher-Ohlin specialization in global production, American Economic Review 93(3), 686-708.

Schott, P. K. (2004) Across-product versus within-product specialization in international trade, Quarterly Journal of Economics 119(2), 647-678.

Shleifer, A. and Vishny, R. W. (1997) A survey of corporate governance, Journal of Finance 52(2), 737-783.

Smith, A. (1776) An Inquiry into the Nature and Causes of the Wealth of Nations, W. Strahan and T. Cadell, London.

Stein, J. (1988) Takeover threats and managerial myopia, Journal of Political Economy 96(1), $61-80$.

Stiglitz, J. E. (1974) Incentives and risk sharing in sharecropping, Review of Economic Studies 41(2), 219-255.

Stiglitz, J. E. and Weiss, A. (1983) Incentive effects of terminations: Applications to the credit and labor markets, American Economic Review 73(5), 912-927.

Strieborny, M. and Kukenova, M. (2016) Investment in relationship-specific assets: Does finance matter?, Review of Finance 20(4), 1487-1515.

Stulz, R. M. (1990) Managerial discretion and optimal financing policies, Journal of Financial Economics 26, 3-27.

Verhoogen, E. (2008) Trade, quality upgrading, and wage inequality in the Mexican manufacturing sector, Quarterly Journal of Economics 123(2), 489-530.

Volpe Martincus, C. and Carballo, J. (2008) Is export promotion effective in developing countries? Firm-level evidence on the intensive and the extensive margins of exports, Journal of International Economics 76, 89-106.

Wurgler, J. (2000) Financial markets and the allocation of capital, Journal of Financial Economics $\mathbf{5 8}, 187-214$.

Xiang, C. (2007) Diversification cones, trade costs and factor market linkages, Journal of International Economics 71, 448-466.

Chen, W.-C. (2012) Innovation and duration of exports, Economics Letters 115(2), 305-308.

Winter, S. G. (1971) Satisficing, selection, and the innovating remnant, Quarterly Journal of Economics 85(2), 237-261.

Zwiebel, J. (1996) Dynamic capital structure under managerial entrenchment, American Economic Review 86(5), 1197-1215. 